\title{
ARTICLE \\ King Leopold's Bonds and the Odious Debts Mystery
}

\section{JOSEPH BLOCHER, Mitu GULATI \& KIM OOSTERLINCK*}

In 1898, in the wake of the Spanish-American war, Spain ceded the colony of Cuba to the United States. In keeping with the law of state succession, the Spanish demanded that the United States also take on Spanish debts that had been backed by Cuban revenues. The Americans refused, arguing that some of those debts had been utilized for purposes adverse to the interests of the Cuban people. This, some argue, was the birth of the doctrine of "odious debts." The odious debts doctrine provides that debts incurred by a non-representative government and utilized for purposes adverse to the population do not need to be repaid by successor regimes.

This Article tests the bistorical evidence in favor of the birth of the odious debts doctrine at the turn of the twentieth century by considering the treatment of perhaps the archetypal odious debt: the debt that Belgium's King Leopold II undertook to finance his horrific exploitation of the Congo Free State (CFS). In 1908, King Leopold was forced to transfer sovereignty over the CFS to Belgium. If the doctrine of odious debts existed at the time, we might expect to see evidence of it in the public debate about whether Belgium was obliged to take on Leopold's debts. Based on original archival research into political debates, litigation regarding Leopold's estate, and contemporary prices and yields of Leopold's bonds, we see no such evidence.

* Professor Blocher and Professor Gulati are on the faculty of law at Duke University School of Law; Professor Oosterlinck is on the faculty of finance at Université Libre de Bruxelles. For conversations and comments on this project, we are grateful to Rick Brooks, Eric Brunstad, Hanoch Dagan, Christine Desan, Avihay Dorfman, David Grewal, Adam Hochschild, Jeff King, Dan Klerman, Roy Kreitner, Jon Macey, Daniel Markovits, and Katarina Pistor. All cited archival sources are on file with the authors, and have been translated by the authors from their original French. 


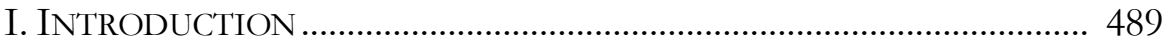

II. KING LEOPOLD AND THE FinANCING OF THE CONGO FREE STATE 495

A. King Leopold Finances a Personal Colony... 495

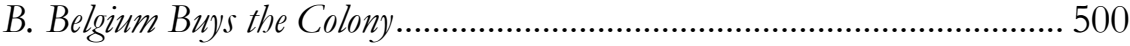

III. WAS THE CONGO FreE StATE'S DEBT Odious?............................. 510

A. Absence of Consent ..................................................................................... 511

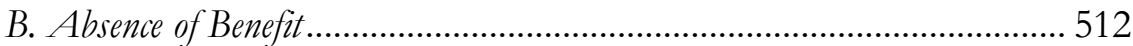

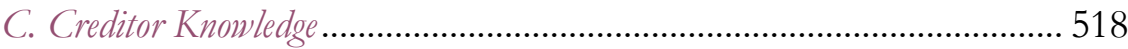

IV. What Did the Market SeE? LeOpoldian Bond PRices And

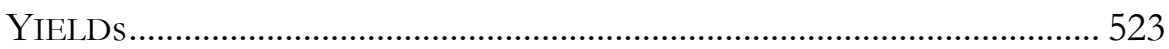

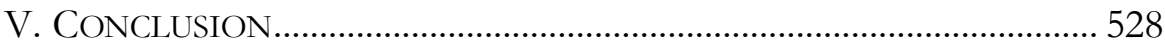




\section{INTRODUCTION}

The doctrine of odious debts is one of the most debated topics in the modern literature on sovereign debt, and has major implications for international law and development. In recent years, some version of the doctrine has been advanced as a possible justification for the repudiation of all or portions of the sovereign debts of Mozambique, Venezuela, Ukraine, Iraq, and Ecuador. ${ }^{1}$

The most commonly articulated version of the doctrine in the academic literature entails three factors and says something along the following lines: debt incurred on behalf of a sovereign by a despotic leader, used for purposes adverse to the interests of the populace, and purchased by creditors who knew that this was likely to occur, is the personal debt of the despot and not attributable to the nation. ${ }^{2}$ The International Law Commission, attempting to get agreement around a definition, provided a somewhat broader account:

For the purposes of the present articles, "odious debts" means: (a) all debts contracted by the predecessor State with a view to attaining objectives contrary to the major interests of the successor State or of the transferred territory; (b) all debts contracted by the predecessor State with an aim and for a purpose not in conformity with international law and, in particular, the principles of international law embodied in the Charter of the United Nations. ${ }^{3}$

The paradigmatic example is of the dictator who incurs debts to foreign creditors in order to purchase arms that his police then use to shoot at prodemocracy protesters. Once the pro-democracy forces succeed in overthrowing the despot, must they still pay for the guns used to shoot at them? The odious debt doctrine would say no.

Whether this rule would be desirable as a matter of market design is a central question in the scholarly debate. On the one hand, a doctrine saying

1. See Cécile Lamarque, Ecuador's Illegitimate Debt, in ECUADOR AT THE Cross-RoAds: FOR AN INTEGRAL AUDIT OF PUBLIC INDEBTEDNESS (2007), https://tinyurl.com/yddqewkq; Rodrigo Olivares-Caminal, Why Does Mozambique Need to Pay Its Non-Odious Debt?, Fin. Times: AlPHAville (Apr. 4, 2019), https://tinyurl.com/ya9u329h; The Stench From a Fishy Business in Mozambique, FIN. TIMES (July 2, 2017), https://tinyurl.com/yaacxet5; Robin Wigglesworth, Venezuela Crisis Raises Talk. of 'Odious Debt' Doctrine, FIN. TiMES (Sept. 11, 2017), https://tinyurl.com/ydeovmzl.

2. See Lamarque, supra note 1 (articulating the doctrine in the context of the Ecuadorian government's invocation of it). See generally JEFF KING, THE DOCTRINE OF ODIOUS DEBT IN INTERNATIONAL LAW: A RESTATEMENT (2016); ODETTE LIENAU, RETHINKING SOVEREIGN DebT: Politics, Reputation, AND Legitimacy in Modern FinANCE (2014); Lee C. Buchheit, Mitu Gulati \& Robert B. Thompson, The Dilemma of Odious Debts, 56 DuKE L.J. 1201, 1218 (2007); Kim Oosterlinck, Sovereign Debt Defaults: Insights From History, 29 OXFORD REV. ECON. POL’Y 697, 709 (2013).

3. Summary Records of the 1425th Meeting, [1977] 1 Y.B. Int'l L. Comm'n 54, U.N. Doc. A/CN.4/SER.A/1977. 
that the debts of despotic leaders shall be deemed personal to the leader and do not have to be repaid by successor governments might deter despotic governments from taking power in the first place, and starve them of funding when they do. ${ }^{4}$ And such a doctrine might help set norms of appropriate behavior, even in the absence of a meaningful sanctioning mechanism. 5 On the other hand, a doctrine of odious debts could potentially incentivize further bad behavior by dictators ${ }^{6}$ or disincentivize investment in countries that might desperately need it. ${ }^{7}$ And even if those problems could be overcome, there are institutional hurdles to implementing it in the first place. ${ }^{8}$

These are fundamental questions about how law shapes markets, and how those markets shape law and governance in return. The sovereign debt market has long been a significant source of governmental finance; it is one important way in which countries raise money for all the things that countries do, including basic expenditures like public works. The doctrine of odious debts has the potential to alter that source-to reshape the sovereign debt market-via a normative evaluation of how a state has been governed. That, in turn, should theoretically pass on the costs of lawless government to those who knowingly financed it, raise the cost of capital for future despots, and encourage better governance going forward.

We do not attempt to resolve the foregoing issues here. Our modest goal is to explore them through a historical case study-one that brings the relationship between markets and government into sharp relief. For roughly fifteen years, King Leopold II of Belgium (hereinafter King Leopold, or just Leopold) ruled the Congo Free State (CFS) as a personal colony, initially financing it through loans before he found a way to make it profitable through exploitation of the native Congolese. ${ }^{9}$ Following an international

4. See Seema Jayachandran \& Michael Kremer, Odious Debt, 96 AMER. ECON. REV. 82, 87 (2006); Ricardo Hausmann \& Ugo Panizza, Odiousness Ratings for Public Debt, Project Syndicate (Aug. 30, 2017), https://tinyurl.com/y7thhnlu.

5. Cf. Richard H. MCADAMS, THE ExPRESSIVE POWERS OF LAW 6-8 (2017) (describing ways in which law communicates values and shapes behaviors beyond its formal role in providing sanctions).

6. Christiana Ochoa, From Odious Debt to Odious Finance: Avoiding the Externalities of a Functional Odious Debt Doctrine, 49 HARV. INT'L L.J. 109, 110 (2008) (arguing that odious debt doctrine, if implemented alone, would set bad incentives for dictators, and that a broader "doctrine of odious finance" is preferable).

7. See, e.g., ERIC A. POSNER \& ALAN O. SYKES, ECONOMIC FOUNDATIONS OF INTERNATIONAL LAW 160-62 (2013) (arguing inter alia that the odious debts doctrine could undesirably reduce lending for public works in autocratic regimes); Katerina Linos \& Jerome Hsiang, Modeling Domestic Politics in International Law Scholarship, 15 CHI. J. INT’L L. 1, 13-14 (2014) (agreeing with Posner and Sykes in part, but arguing that the doctrine of odious debt might nonetheless be applicable in cases of personalistic dictatorships); Raghuram Rajan, Odious or Just Malodorous?, 41 FIN. \& DEV. 54, $54-55$ (2004) (discussing unintended consequences of an odious debts regime).

8. See Paul B. Stephan, The Institutionalist Implications of an Odious Debt Doctrine, 70 LAW \& CONTEMP. PROBS. 213, 214 (2007) (arguing that "no satisfactory mechanism exists for instituting an odious debt doctrine").

9. Joseph Blocher \& Mitu Gulati, Transferable Sovereignty: Lessons from the History of the Congo Free 
human rights campaign that publicized the horrors of his misrule, Leopold was forced to give up sovereign control, and Belgium was compelledreluctantly-to purchase the colony from its king in 1908.10 The atrocities in the CFS are by now well-known. But what of King Leopold's debts? Who bore responsibility for those? The literature on sovereign debt has yet to investigate whether, when Leopold was ejected from power, there was a debate over the odiousness of his debts and whether Belgium, as the successor government, was obliged to take them on.

This historical lacuna is significant for the modern debate. The case for a contemporary doctrine of odious debts is largely predicated on an argument about whether the law of state succession (which would typically require a new regime to honor the debts of its predecessor) has historically recognized an exception for odious debts. It is important, therefore, to be clear about the exception's historical lineage both as a matter of justification and because doing so can help sharpen the normative debate, providing concrete examples with which to evaluate whether the invocation or noninvocation of the doctrine was desirable.

Throughout history, there have been many situations in which a regime's debts have been repudiated following political upheaval. ${ }^{11}$ Prominent examples include the debts of the Russian Tsar, Imperial China, and the U.S. Confederacy. ${ }^{12}$ In some cases, certain illegitimate debts have received what looks to be a market penalty in the expectation that they faced a higher than normal likelihood of repudiation-possible evidence that repudiation, in the context of despotic governance, is a real possibility. ${ }^{13}$

But it is not easy to establish whether any such repudiations were done out of a sense of legal obligation or for other reasons, such as a perception that the reputational costs would be minimal. Some find enough in the historical record to suggest that the doctrine is long established, ${ }^{14}$ and that

State, 69 DUKE L.J. 1219 (2020). The King's father, Leopold I, also pursued colonial ambitions, but without the same drive or scope as his son. Id. at 1226-28

10. This was itself a remarkable interaction between law and markets. For a discussion, and suggestion that the forced sale of the Congo Free State might have useful implications for modern international law and practice, see $i d$. at 1252-72.

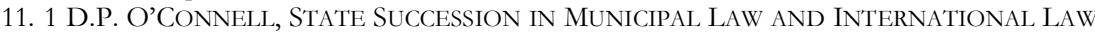
19-21 (2d ed. 1967) (discussing the evolution of theories of State succession, including the renunciation of predecessor debts).

12. See Buchheit et al., supra note 2 , at $1224,1221,1213$ respectively.

13. See, e.g., Stephanie Collet \& Kim Oosterlinck, Denouncing Odious Debts, J. Bus. ETHics 205, 207 (2019); Kris James Mitchener, Kim Oosterlinck, Marc D. Weidenmier \& Stephen Haber, Victory or Repudiation? Predicting Winners in Civil Wars Using International Financial Markets, 60 J. BANKING \& FIN. 310, 313 (2015).

14. See e.g., Jeff A. King, Odious Debt: The Terms of the Debate, 32 N.C. J. INT'L \& COM. REG. 605, 607 (2007) (describing the doctrine of odious debt as "well established-subject to some qualifications-in cases of government succession"); Robert Howse, U.N. Conference on Trade \& Development, Discussion Paper No. 185: The Concept of Odious Debt in Public International Law, at 1, U.N. Doc. UNCTAD/OSG/DP/2007/4 (July 1, 2007) (concluding that an "odiousness" exception to the 
when odious debts have been repaid, such as in the case of the South African apartheid-era debts, it has been because of other reasons, such as the desire to preserve a reputation as a good debtor. ${ }^{15}$ Others point out that no court, international or municipal, has ever explicitly recognized the existence of such a doctrine, ${ }^{16}$ and argue that there is little historical evidence that any of the payments or non-payments of despotic debts were driven by beliefs about legal doctrine. ${ }^{17}$

The CFS could be an especially intriguing part of this historical analysis because King Leopold's debts were passed to Belgium in the years between the two most-discussed historical precedents in the odious debt literature. ${ }^{18}$ Those are the Spanish-American post-war treaty negotiation from 1898 and an international arbitration case involving Costa Rica and Great Britain in 1923.19 Both arguably support the existence of a legal doctrine of odious debts. ${ }^{20}$ If the story of the CFS does as well, that would strengthen the historical chain. If not, it raises serious questions about the historical basis for the doctrine.

The 1898 event was the treaty negotiation between the Spanish and American governments over responsibility for Spanish debt backed by Cuban revenue streams that took place in the wake of the Spanish-American

obligation to repay debts "may indeed form part of the content of equity as 'a general principle of law of civilized nations"').

15. HOwSE, supra note 14, at 13-14; KING, supra note 2, at 12; Patricia Adams, Iraq's Odious Debts, 526 CATO INST. POL'Y ANALYSIS 1, 5 (2004).

16. Tom Ginsburg \& Thomas S. Ulen, Odious Debt, Odious Credit, Economic Development, and Democratization, 70 LAW \& CONTEMP. PROBS. 115, 117 (2007); Olivares-Caminal, supra note 1, at 3.

17. See e.g., Christoph G. Paulus, The Evolution of the "Concept of Odious Debts," 68 HeIDELBERG J. INT'L L. 391, 402 (2008); Andrew Yianni \& David Tinkler, Is There a Recognized Doctrine of Odious Debt? 32 N.C. J. INT'L L. \& COMM. REG. 749, 771 (2007).

18. Even when Congo is mentioned, the CFS generally is not. See, e.g., HowSE, supra note 14, at 10-16 (enumerating "Key Transitional Contexts Where the Concept of Odious Debt Has Been Invoked," but not mentioning the CFS). Scholars have noted the possible application of the doctrine in connection with the dictatorship of Mobutu Sese Seko, who ruled the Congo (which he renamed Zaire) from 1965 to 1997. See, e.g., James V. Feinerman, Odious Debt, Old and New: The Legal Intellectual History of an Idea, 70 LAW \& CONTEMP. PROBS. 193, 210 (2007); Ginsburg \& Ulen, supra note 16, at 115, 125; see also Joseph Hanlon, Defining "Illegitimate Debt": When Creditors Should be Liable for Improper Loans, in SOVEREIGN DEBT AT THE CROSSROADS: CHALLENGES AND PROPOSALS FOR RESOLVING THE THIRD WORLD DEBT CRISIS 109, 123 (Chris Jochnick \& Fraser A. Preston eds., 2006) ("There is perhaps no clearer example of odious debt.").

19. See, e.g., Anna Gelpern, What Iraq and Argentina Might Learn From Each Other, 6 CHI J. INT'L L. 391, 404, 411-12 (2005); Lamarque, supra note 1, at 5; Michael H. Hoeflich, Through a Glass Darkly: Reflections upon the History of the International Law of Public Debt in Connection with State Succession, 1982 U. ILL. L. REV. 39, 60 (1982); Jayachandran \& Kremer, supra note 4, at 83; Odette Lineau, Who is the "Sovereign" in Sovereign Debt?: Reinterpreting a Rule-of-Law Framework, from the Early Twentieth Century, 33 YALE J. INT'L L. 63, 65, 67 (2008).

20. Some international law historians note even earlier instances of repudiation, such as the Mexican repudiation of Emperor Maximilian's debts in 1867, but the facts of those instances are less supportive of an odious debt doctrine than the Spanish-American debt negotiations. See Sabine Michalowski, The Doctrine of Odious Debts in International Law, in HOw TO CHALLENGE ILLEGITIMATE DEBT 17 (Max Mader \& André Rothenbühler eds., 2009). 
war. ${ }^{21}$ The U.S. delegation refused to take on some of the Spanish debt on the grounds that the proceeds from those debts had been used to suppress the Cuban independence movement. ${ }^{22}$ Researchers have argued that the bond markets in 1898 understood the doctrine well enough to factor its impact into bond prices, such that the bonds that had the potential to be deemed odious traded at a discount as compared to those that were not.23

The 1923 arbitration was a dispute between Costa Rica and Great Britain. The Royal Bank of Canada had made loans to the Costa Rican government run by Frederico Tinoco, but the proceeds never reached the state's coffers. After Tinoco was overthrown in 1919, the new government in Costa Rica refused to pay the loans. The matter went to arbitration in front of the then-Chief Justice of the U.S. Supreme Court, William Howard Taft, who concluded that the lending was so "full of irregularities" that the Royal Bank could not legitimately claim to have thought that it was making its loan to the Costa Rican government rather than to Mr. Tinoco himself.24

Both cases can be read to suggest that something akin to an odious debt doctrine existed in the late nineteenth and early twentieth centuries in that successor governments refused to pay certain debts on the grounds that the proceeds of the debts were not used for the benefit of the populations being asked to pay. ${ }^{25}$ But one can also tell these stories in terms of power

21. Michalowski, supra note 20, at 17; Ashfaq Khalfan, Jeff King \& Bryan Thomas, Advancing the Odious Debt Doctrine 14-16 (Mar. 11, 2003) (unpublished manuscript), https://cisdl.org/public/ docs/pdf/Odious_Debt_Study.pdf.

22. ReX J. ZeDAlis, Claims Against IRAQI OIL AND GAS: LEgAl CONSIDERATIONS AND LESSONS LEARNED 28 (2010); Jayachandran \& Kremer, supra note 4, at 83. For a fuller, and more skeptical, historical discussion, see Louis A. Pérez, Jr. \& Deborah M. Weismann, Public Power and Private Purpose: Odious Debt and the Political Economy of Hegemony, 32 N.C. J. INT'L L. \& COM. REG. 699, 717-20 (2007) (suggesting that the U.S. refusal is best understood "the logic of the victor imposing the terms of peace on the vanquished").

23. See Stephanie Collet, The Financial Penalty for "Unfair" Debt: The Case of the Cuban Bonds at the Time of Independence, 17 EUR. REV. ECON. HIST. 364, 364 (2013). The leading U.S. commentator on these matters in the early twentieth century does appear to draw on the Spanish-American negotiations when, in 1947, he writes about which debts should and should not carry over in a cession of territory. However, it is not clear whether Hyde is articulating a moral principle or a legal one. Hyde wrote:

$[T]$ erritory, if occupied by human beings, is not, like a mere chattel, to be subjected to such fiscal or other use as may suit the convenience or caprice of the existing governmental authority. On principle the resources of that territory should not be regarded as capable of complete hypothecation save under conditions which do not appear to be essentially adverse to the welfare of the occupants.

1 Charles Cheney Hyde, InTERnATIONAL LAW: CHIEFly AS INTERPRETED AND APPlied By THE UNITED STATES $\int 126$ (2d rev. ed. 1947).

24. Buchheit et al., supra note 2, at 1217.

25. The following statement, which appears in the introduction of a book arguing that some of the Greek debt was odious, is illustrative:

Future generations will not thank us for the excesses of the current age. They may even look up the definition of the 'odious' debt. This is a legal theory, established in the 1920s, which holds that national debt incurred by a government for purposes that do not serve the best interests of the nation should 
dynamics. After all, the Spanish were apparently willing to arbitrate the specifics of which debts should be allocated to them, but the United States was not interested in any such nuanced parsing. It had won the war and was not going to take on the Spanish debts backed by Cuban revenues. ${ }^{26} \mathrm{~A}$ similar story can be told about the Tinoco case, again reflecting the preferences of the United States. ${ }^{27}$

In short, history is central to the debate, and the stakes are high. And yet the historical record is thin, which makes historical claims contingent and fragile. The transfer of sovereign control and associated debts from King Leopold to Belgium in 1908 thus has the potential to shed light on the extent to which the key players at the time understood there to be a doctrine of odious debts. It also provides a case study of how markets-specifically debt markets - can influence and be influenced by debates about proper law and governance. We are able to illustrate that story in part through original archival research, including parliamentary debates and litigation materials. ${ }^{28}$

Part I describes the story of King Leopold's misrule of the CFS, focusing on the two portions of the story that bear on the question at hand: how he financed his endeavor, and the transfer of responsibility for his debt upon his removal. Part II analyzes how closely the story of the CFS fits within the traditional odious debt framework. We find that Leopold's bonds (some of them, at least) satisfy the traditional three-part definition of odious debt, but also that there was little discussion of treating them as such at the time.

Part III uses data on bond prices for both the CFS and Belgium to address whether the market expected the odious debts to be repudiated. If so, then Belgium's eventual adoption of these debts would have come as a happy surprise to investors and should show up as a drop in yields of the bonds of the CFS. We find no such evidence, in contrast to what prior scholars have found in the United States-Spain context, where the markets appeared to anticipate which debts would be repudiated. ${ }^{29}$ In sum, the story of the CFS seems to be a paradigmatic case of odious debt, yet neither public debate nor bond yields show evidence that it was treated as such. This casts doubt on whether the doctrine was recognized at the time.

not be enforceable

JASON MANOLOPOULOS, GREECE'S ‘ODiOUS’ DEBT, at xiv (2011).

26. Sarah Ludington, Mitu Gulati \& Alfred L. Brophy, Applied Legal History: Demystifying the Doctrine of Odious Debts, 11 TheORETICAL INQUiRIES L. 247, 255 (2010); see also Pérez \& Weismann, supra note 22, at 718-19 (describing the Spanish-American peace settlement as "negotiations between two countries vastly unequal in power").

27. Ludington et al., supra note 26, at 265.

28. These original sources are in French; we have provided translations.

29. See Collet, supra note 23, at 364-65. 


\section{KING LEOPOLD AND THE FINANCING OF THE CONGO FREE STATE}

In order to evaluate King Leopold's borrowing, the uses to which the borrowed funds were put, and the financial obligations ultimately shouldered by the Congolese people after the King was ejected, we tell the story of the CFS in two parts. First, we describe the debt the King undertook to finance his colonial venture. Second, we detail the transfer of those liabilities to Belgium, which then allocated the responsibility of repayment to the CFS itself.

\section{A. King Leopold Finances a Personal Colony}

One advantage of controlling your own country is that you can issue bonds. This eventually was to become a source of revenue for Leopold almost equal to that of rubber. All told, the king issued bonds worth more than a hundred million francs, or roughly half a billion of today's dollars. Some bonds he sold; some he gave to favorites; some he kept for his personal portfolio; some he used in lieu of cash to pay for public works projects in Belgium. Since the bonds were for terms as long as ninety-nine years, Leopold knew that paying back the principal would be somebody else's problem. Supposedly the bond money was for development in the Congo, but little of it was ever spent there. ${ }^{30}$

Because our story brings together markets and law, it is important to begin with an explanation of the ways in which Leopold relied on markets to establish his own personal colony. His motivations and methods frequently blended private control and political sovereignty. The colony existed simultaneously as personal property and a sovereign state, with Leopold at the head as both owner and King. ${ }^{31}$

This arrangement-political rule as a means of economic profit-was deeply ingrained in Leopold. As a young man, he visited Seville, where he spent an entire month combing through colonial documents. He wrote to a friend, "I am very busy here going through the Indies archives and calculating the profit which Spain made then and makes now out of her colonies." 32 He became fascinated with a treatise called Java; or, How to

30. Adam Hochschild, King Leopold's Ghost: A Story of Greed, Terror, AND HEROISM IN COLONIAL AFRICA 168 (1999). One question we have yet to resolve is who purchased the bonds.

31. This hybrid status illuminates important conceptual questions about the relationship between property and markets on the one hand and sovereignty and politics on the other. See generally Eyal Benvenisti, Sovereignty and the Politics of Property, 18 THEORETICAL INQUIRIES L. 447 (2017) (discussing the tension between property and sovereignty as well as the related tension between economics and politics).

32. HoCHSCHILD, supra note 30 , at 37. 
Manage a Colony, in which an English lawyer explored colonial concessions and other ways of profiting via private companies and colonies. ${ }^{33}$

Without an army willing to engage in conquest (Belgium had no colonial appetite at the time), and with much of the globe already claimed by European powers, Leopold turned to purchase as his method of acquisition and Africa as his target, pushing his representatives-including Henry Stanley-to acquire as much sovereign territory as they could. In King Leopold's Ghost, Adam Hochschild provides one example from the Congo, in which the chiefs of Ngombi and Mafela, in return for "one piece of cloth per month to each of the undersigned chiefs, besides present of cloth in hand," agreed to:

$[F]$ reely of their own accord, for themselves and their heirs and successors for ever... give up to the said Association the sovereignty and all sovereign and governing rights to all their territories ... All roads and waterways running through this country, the right of collecting tolls on the same, and all game, fishing, mining and forest rights, are to be the absolute property of the said Association. ${ }^{34}$

The "Association" referenced here was a shell NGO that Leopold created as he was trying to convince the world that his motives in the Congo were humanitarian. Playing the other European powers off of one another and, crucially, obtaining the support of the United States, he was able to win international recognition of the CFS by the time of the Berlin Act in 1885.35

This was a triumph, but a hollow one if Leopold could not afford to get his new enterprise off the ground financially. In 1887, following two years of negotiations, Leopold arranged his first bond issuance, which would establish the basic public debt of the CFS. ${ }^{36}$ This was no mean feat. Just to get the bonds listed on the Paris stock exchange, he had to offer the French a favorable adjustment of the CFS's border with the French Congo. ${ }^{37}$ And due to the difficulty of finding a guarantee for prospective investors (the Rothschilds and French banks refused to act as intermediaries), the bonds were not actually put on the market until February 1888. 38

33. Id.

34. Id. at 72. The agreement also ominously pledged "to assist by labour or otherwise" with the Association's "works, improvements or expeditions." Id.

35. GeOrges NZONGola-Ntalaja, The Congo: From Leopold to Kabila: A PeOple's HISTORY 266 (2002).

36. NeAL AsCHERSON, THE KING INCORPORATED: LEOPOLD II IN THE AGE OF TRUSTS 147 (1964).

37. Robert Harms, King Leopold's Bonds, in The Origins of Value: The Financial INNOVATIONS THAT CREATED MODERN CAPITAL MARKETS 343, 345 (William N. Goetzmann \& K. Geert Rouwenhorst eds., 2005).

38. ASCHERSON, supra note 36, at 147. 
The first half of the issuance sold well, but by April 1889-and despite Leopold's efforts to artificially prop up prices-the selling price of the first half had fallen below the planned listing price of the second half. ${ }^{39}$ Less than half of this second issue was sold, ${ }^{40}$ despite the Belgian government's pledge to pay for some of it, and the enterprise only ended up raising roughly 30 million francs-far less than expected. ${ }^{41}$ This issuance was, in short, unsuccessful. 42

It is difficult to know much about the balance sheets of the CFS during this period, because it was not until years later that the State even made a pretense of releasing anything like financial reports. ${ }^{43}$ In Belgium, members of the Parti Ouvrier Belge ${ }^{44}$ such as Emile Vandervelde denounced the lack of information received from the CFS. ${ }^{45}$ The Belgian government, however, tried to limit questions regarding the finances of the CFS on the grounds that it was a foreign country. ${ }^{46}$ Whatever the precise figures, it is clear that Leopold's colony was not profitable at the outset, and that he was personally sinking further and further into debt. ${ }^{47}$ David Van Reybrouck concludes that "[b]y 1890 [Leopold] had already spent 19 million francs on Congo. The

39. Id. at $147-48$.

40. The full list and the amounts subscribed by the various banks are provided in Appendix 1.

41. Id.

42. Thomas Pakenham, The SCRAmble For AFrica: THE White MAN's CONQUEST OF THE DARK CONTINENT FROM 1876 TO 1912, at 398 (1991) ("Leopold went to the European market and tried to raise a huge 150-million-franc (L6 million) interest-free loan based on a lottery (like premium bonds today). The first tranche of 10 million francs (L400,000) had to be discounted at 83 percent of par, despite Leopold's desperate attempts to hold the price at 92 . Then the second tranche, 60 million francs (L240,000), flopped disastrously. Less than half were taken by the public.”).

43. An internal memo from the Belgian Finance Minister dated from March 1895 deplored the poor quality of the data: "The conclusion to be drawn from the attached note from Mr. VanCutsem is that it is impossible, by means of the figures provided by the State of the Congo to see clearly in the situation and to appreciate what may be the needs in more or less distant future." Memorandum from the Ministry of Finance (Mar. 20, 1895) (on file in box 588 in the MinFin Oud files at the Archives Générales, du Royaume) [hereainfter Archives Générales files].

44. The equivalent of the Labour party.

45. Annales Parlementaires [Parliamentary Annals], Chambre des représentants [House of Representatives], Mar. 13, 1903 (Belg.).

46. Annales Parlementaires [Parliamentary Annals], Chambre des représentants [House of Representatives], Feb. 28, 1905 (Belg.).

47. Roger Anstey, King LeOpold's LegACy: THE CONGo Under Belgian Rule 1908 1960 , at 4 (1966) ("From the later 1880's the task of ruling a territory eighty times the size of Belgium threatened to break Leopold financially."); PAKENHAM, supra note 42, at 397 ("By 1890 twelve years after the King had first commissioned [the explorer] Stanley to open up the Congo, the bankers were losing patience .... The state's whole income was less than the proceeds from one small factory in Europe ....”); DAVID VAN REYBROUCK, CONGO: THE EPIC HiSTORY OF A PEOPLE 79 (Sam Garrett trans., 2010) ("Between 1876 and 1885 he invested no less than 10 million Belgian francs, but the revenues in 1886 amounted to no more than seventy-five thousand francs. By 1890 he had already spent 19 million francs on Congo. The huge fortune inherited from his father had gone up in smoke. The king was virtually bankrupt."); see Harms, supra note 37, at 344 ("The shaky financial structure that underpinned the activities of the Congo Independent State included bonds, unissued bonds, coerced loans, fake loans, a lottery, concessions of territory, stocks held by legitimate investors, and stocks held by straw men.’). 
huge fortune inherited from his father had gone up in smoke. The King was virtually bankrupt." 48

Finance became the King's obsession: "It was now almost impossible for him to see any event, personal or political, except in terms of its possibilities in credit." 49 Eventually, and in violation of an earlier pledge that the colony would not be a drain on Belgium's finances, ${ }^{50}$ the King sought a loan from Belgium itself. That loan was made-interest free, in the amount of 25 million francs-in return for his agreement to give the Congo to Belgium in his will..$^{51}$ It seems likely that this was a quid pro quo, 52 though it was not officially acknowledged as such.

In a covering letter accompanying the will, Leopold wrote that if "it pleases the country to contract more binding ties with my possessions in the Congo, I shall not hesitate to put them at its disposal. I would be happy to see Belgium during my lifetime in full possession of them." 53 Moreover, Leopold agreed that "at the end of ten years, either the loan would be repaid, or the Free State would be handed over to Belgium." 54 The colony, in other words, was security for the loan. ${ }^{55}$ Or, to the degree that Leopold truly did plan to turn the colony over to Belgium, these initial investments might be considered a kind of deposit. ${ }^{56}$

48. REYBROUCK, supra note 47 , at 79.

49. ASCHERSON, supra note 36, at 148.

50. Martin EWANS, European Atrocity, African Catastrophe: Leopold II, the CONGO FREE STATE AND ITS AFTERMATH 112 (2002); HOCHSCHILD, supra note 30, at 91-92.

51. HOCHSCHILD, supra note 30, at 94-95; PAKENHAM, supra note 42, at 399.

52. ANSTEY, supra note 47, at 3 ("There seems little doubt that he agreed to the 1890 arrangement as a condition of obtaining a desperately needed loan from a Belgium which was experiencing some stirrings of colonial interest and which therefore sought to establish a firm lien on her sovereign's colony.").

53. ASCHERSON, supra note 36, at 187; EWANS, supra note 50, at 120; see also HOCHSCHILD, supra note 30, at 101 ("Leopold's will treated the Congo as if it were just a piece of uninhabited real estate to be disposed of by its owner."); LOUIS DE LICHTERVELDE, LÉOPOLD II 246-27 (1926) ("This transmission of sovereignty by testament—as if sovereignty were part of a patrimony — recalls the high Middle Ages and is still without parallel in the modern world.") (translation provided by author); STEVEN PRESS, ROGUE EMPIRES: CONTRACTS AND CONMEN IN EUROPE'S SCRAMBLE FOR AFRICA 18 (2017) (describing James Brooke's similar power to devise governing rights over Sarawak by will).

54. EWANS, supra note 50, at 121.

55. In fact, Leopold gave Belgium an option "to annex the Independent State of the Congo with all the possessions rights and advantages attached to the sovereignty of that State . . . but also on condition of assuming the responsibilities of the said State towards third parties." 1 DEMETRIUS C.

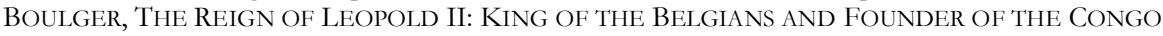
STATE 1865-1909, at 214-15 (1925) (quoting a Convention concluded between the Belgian Government and the Congo from July 3, 1980). Belgium could have exercised its option in 1901, but "there was no sufficiently strong and determined body of opinion either in the Cabinet or in Parliament to insist on this course, whilst Leopold publicly worked against immediate annexation." ANSTEY, supra note 47 , at 3 . Within a decade, Belgium would pay a much higher price, raising the question of what changed so significantly in such a short time, and whether and why the international pressure on Belgium was so powerful.

56. ASCHERSON, supra note 36, at 186. Because Congo remained a colony-now of Belgium, rather than of Leopold - the questions of state succession and decolonization would not become fully operative until independence in 1960. For an exploration of those questions, focusing particularly on 
The bonds and loans helped keep the CFS afloat temporarily, but the situation was not sustainable. ${ }^{57}$ Just how unsustainable is difficult to say, since even in the early 1890s it was apparent to Belgian politicians that Leopold was "concealing financial data even from the Congo's own staff, [as] he continued to carpenter a variety of schemes to raise further credit." 58 In late 1894, the Belgian government became aware of a deal the King had proposed to conclude with a concession company (partly owned by the British, a fact that raised concerns in Belgium) within the Congo. The Belgian Prime Minister's cabinet "unanimously demanded that Leopold should drop the Sociéte de Manyema project and provide them with full accounts of Congolese finances, and at the end of the year, [the Foreign Minister] sponsored a bill for immediate annexation of the Congo." 59 An annexation treaty was drawn up to that effect in January 1895.60

The King then revealed that he had borrowed 5 million francs from Alexandre Browne de Tiège (an Antwerp banker) in 1892, which—thanks in part to the failure of the Sociéte de Manyema project-he would be unable to repay when it came due in July 1895. ${ }^{61}$ This made annexation both more pressing and more problematic, for it added 5 million francs to the expected cost, and cost had always been a primary driver of anti-colonial sentiment in Belgium. ${ }^{62}$ The annexation bill foundered that summer, and the government ended up loaning Leopold the money he needed, ${ }^{63}$ with the colony (40 million acres of it, anyway) offered up as collateral. ${ }^{64}$

One aspect that makes this story so extraordinary is that, as Jean Stengers' research later demonstrated, "Leopold extracted the 5,000,000 from the Government by telling them a flat lie about a debt which was pure fiction." 65 There had never been a loan in the first place. Thus:

[1]nstead of being transmitted into the account of Alexandre Browne de Tiège, most of the money was in turn 'paid' by the State Treasury to Leopold himself, to cover 'advances' made by the King to the State. Leopold had thus repaid himself for an advance made

the work of Daniel Patrick O'Connell and Mohamed Bedjaoui, see Michael Waibel, Decolonization and Sovereign Debt: A Quagmire (Cambridge Faculty of Law Legal Studies, Paper No. 15/2019, 2019).

57. EWANS, supra note 50, at 157 ("Even with the Fr 25 million loan from the Belgian government and the ability to levy duty on imports, the Free State remained, during the early 1890 s, on the verge of bankruptcy.").

58. ASCHERSON, supra note 36, at 188 .

59. Id. at 189

60. EWANS, supra note 50, at 168; see also PAKENHAM, supra note 42, at 588 ("[ []n 1895, . . Leopold had almost thrown in the sponge and handed over the Congo voluntarily to Belgium.").

61. ASCHERSON, supra note 36, at 190.

62. Id.

63. Id.

64. EWANS, supra note 50, at 166.

65. ASCHERSON, supra note 36, at 193. 
by himself to himself, and done so with somebody else's money. ${ }^{66}$

\section{B. Belgium Buys the Colony}

What these loans financed was, as is now well-recognized, a horror. ${ }^{67}$ The scope and scale of the atrocities committed in the CFS have been chronicled powerfully by others, and we will not recap that literature here except to the degree that it bears directly on the question of whether King Leopold's odious acts involved odious debts in a legal sense. And that question, in turn, arises because those debts were eventually passed on to a successor sovereign: Belgium.

When the nature and scale of Leopold's brutality against the Congolese people became undeniably apparent, the "Belgian Solution"—acquisition of the colony by Belgium - was generally regarded by reformers as the best, and perhaps only viable, option for the future of the Congo. ${ }^{68}$ But neither Belgium (the buyer) nor Leopold (the seller) were particularly enthusiastic about the prospect.

Belgium, of which Leopold was king (he had to get Parliamentary approval to rule the CFS in his private capacity), had not traditionally demonstrated much of an appetite for colonies. ${ }^{69}$ Opposition to colonization - in Belgium as elsewhere-was driven partially by financial considerations, and was especially pronounced on the political left. In the words of a Belgian Socialist newspaper when annexation was discussed in 1895: "What is one to say about the criminal folly of our governors who are light-heartedly preparing to attach to Belgium a gigantic territory, when they are still unable to ensure the safety and well-being of the children of the Mother-land?" 70 And when Belgium's option to annex the Congo (acquired in exchange for the 1890 loan) came due in 1901, "there was no sufficiently strong and determined body of opinion either in the Cabinet or in Parliament to insist on this course [of exercising the option], whilst Leopold publicly worked against immediate annexation."’71 According to Louis

66. Id. at 193-94.

67. Joseph Conrad's Heart of Darkness was based on his experience in the Congo Free State, and Colonel Kurtz's famous final lines-“The horror! The horror!"-are apt. There are innumerable accounts of Leopold's misrule, see, e.g., EWANS, supra note 50, at 163 ("Africans often found themselves having to work extortionate periods for nominal payment, while, as the time left to them to grow their own food became limited, famine and disease followed."); HOCHSCHILD, supra note 30, at 4 ("[Congo Free State] was the first major international atrocity scandal in the age of the telegraph and the camera.").

68. HOCHSCHILD, supra note 30, at 257.

69. 1 BOULGER, supra note 55 , at 33 ("[T] he national character, or perhaps it would be more correct to say the national experiences, rendered the Belgian people averse to any policy of adventure outside their borders.").

70. ASCHERSON, supra note 36, at 271 (quoting the socialist newspaper Le Peuple).

71. ANSTEY, supra note 47 , at 3. 
Bertrand, the colony had become profitable by that time, and the Belgian government essentially acceded to Leopold's desire to keep it. ${ }^{72}$

Leopold's own opposition to the Belgian Solution was driven in part by financial concerns, and in part by a sense that the colony was his own personal property..$^{73}$ In effect, he saw the matter as a question for the market to resolve- the CFS was a product of his investment, and could only be taken on his terms. In the spring of 1906, Leopold described the impending transfer (which by then was inevitable, though he would drag it out for another two years) as theft:

My rights to the Congo are not for sharing; they are the fruits of my labours and my expenditures... . The adversaries of the Congo are pressing for immediate annexation. These persons no doubt hope that a change of regime would sabotage the work now in progress and would enable them to reap some rich booty. ${ }^{74}$

Implicitly invoking John Locke, he wrote that "the Congo has been, and could have been, nothing but a personal effort. There is no more legitimate or respectable right than that of an author over his own work, the product of his own labor...." 75

In practice and in his own mind, Leopold tended to blur the distinction between personal and sovereign control. In a later trial regarding his personal succession, a lawyer defending the Belgian state explained:

$[\mathrm{H}]$ ow can we explain the fact that Leopold II distinguished between his personality as the assignee of the removed Crown Foundation assets and the Free State, to the point that he felt he had to transfer all or part of these assets to the Free State, by a subsequent formal provision of the decree? In the simplest way in the world.

72. Annales Parlementaires [Parliamentary Annals], Chambre des représentants [House of Representatives], Feb. 28, 1905, at 815 (Belg.) ("By that time, gentlemen, Congo Free State had become prosperous and its leader did not want Belgium to take over at that time. The Belgian government, mandated by its ministers' body to defend Belgium's interests vis-à-vis the Congo Free State, neglected these interests entrusted to it. He let the six-month date pass within which Belgium could take over Congo or impose new conditions on the independent state.").

73. U.S. legal scholarship is rich with discussions of the relationship between sovereignty and private property. The classic reference is Morris R. Cohen, Property and Sovereignty, 13 CORNELL L.Q. 8 (1927) (arguing that the understanding of sovereignty requires consideration of the nature of private property). For a recent discussion, see generally the second issue of 18 THEORETICAL INQUIRIES L. (2017) (including contributions by Eyal Benvenisti, Jean L. Cohen, Hanoch Dagan \& Avihay Dorfman, Sergio Dellavalle, Larissa Katz, Martti Koskenniemi, Thomas W. Merrill, Katharina Pistor, Arthur Ripstein, Joseph William Singer, Laura S. Underkuffler, and Jeremy Waldron).

74. EWANS, supra note 50, at 224 (emphasis added); see also PAKENHAM, supra note 42, at 655 (quoting a "royal letter" issued by King Leopold on June 3, 1906, claiming "[m]y rights over the Congo cannot be shared; they are the fruits of my labours and my expenditure .... It behoves me to proclaim these rights to the world.").

75. SAMUel H. Nelson, COlOnialism in the CONGO BASIN 1880-1940, at 85 (1994). 
By the fact that the King, who had only rather vague notions on the exact legal scope of his sovereignty, believed in the possibility of a disjunction, a duality between the absolute state that was the Congo Free State and the personality of his sovereign, whereas such a disjunction was contrary to the most elementary principles of public law. ${ }^{76}$

He further asserted that "the Congo Free State was an absolute state, or even the prototype of the absolute state." 77 This view was shared by the Public Prosecutor in the litigation over his assets between his children and the Belgian state that followed his death. ${ }^{78}$

In part reflecting this vision of absolute control, Leopold continued to contemplate alternatives to the Belgian Solution, all of which involved sales or transfers that would be to his benefit:

They do not understand the true interests of the country. It would probably be better to sell the Congo to France ... Is it not wretched to have been the King of this State for twenty-two years and to have kept nothing for oneself? After all, I am seventy-two years old and will not have long to benefit from it. ${ }^{79}$

Leopold had insisted that his goals in the Congo were humanitarian, and that he had pursued them at personal cost, and he might even have come to believe that. But his words and actions also showed that he viewed the CFS as a piece of property in which he had invested personal funds, and from which he expected a return.

Leopold's grasp on the CFS was significantly loosened in 1906. Early that spring, Félicien Cattier published Etude sur la Situation de L'Etat Indépendant du Congo, which provided a devastating critique of his rulelargely on financial grounds. ${ }^{80}$ Increased pressure from the British government (some of it brought on by revelations about Leopold's "poaching" of territory in the Nile Valley) and British press (reporting on the apparent persecution of British subjects) took its toll. ${ }^{81}$ But what really

76. Cour d'appel [CA] [Court of Appeals] Bruxelles, Plaidoirie de Me Eugène Hanssens, avocat de la cour d'appel de Bruxelles pour l'état belge intimé, contre S.A.R. la princesse Louise de Belgique et S.A.R. la princesse Stéphanie de Belgique, Comtesse Lyonay appelantes at 60 (Belg.) [hereinafter Cour d'appel de Bruxelles].

77. Id. at 72 .

78. Tribunal de Première Instance [Tribunal of First Instance] Bruxelles, 2e ch., Avis du Ministère Public et Jugement, at 52.

79. EWANS, supra note 50, at 226 (emphasis added).

80. See generally FÉLICIEN CATTIER, ÉTUDE SUR LA SiTUATION DE L'ÉTAT INDÉPENDANT DU CONGO 20 (F. Larcier \& A. Pedone eds., 1906) (critiquing the exploitative, monopolistic, and absolutist fiscal policies of colonial empires, particularly that of Leopold in the CFS).

81. W. Roger Louis, The Stokes Affair and the Origins of the Anti-Congo Campaign, 1895-1896, 43 Revue Belge De Philologie ET D’Histoire [RBPH] 572, 572-584 (1965). 
seemed to make the difference was the threat of a growing anti-Congo movement in the United States, ${ }^{82}$ which in the 1880s had been the first and most important supporter of Leopold's claims. ${ }^{83}$

Leopold therefore had to sell, ${ }^{84}$ but the terms of the deal were, from a modern perspective, generous. ${ }^{85}$ Belgium not only took over his debt obligations, but also committed to pay for many of his ongoing pet construction projects in Belgium (palaces, gardens and more), and pledged a 50 million franc payment to Leopold "as a mark of gratitude for his great sacrifices made for the Congo." 86 As Hochschild notes, "[s]ome of the debt the outmaneuvered Belgian government assumed [and then put on the Congolese] was in effect to itself-the nearly 32 million francs worth of loans Leopold had never paid back." 87

To ensure that his pet projects would outlive him, regardless of whether the Belgian government continued to support them, Leopold created the Niederfüllbach Foundation in 1907 and capitalized it with assets generated from the resources of the CFS.88 After his death, both the Belgian government and his daughters sought to take possession of those assets, and a court battle ensued. A key question in that litigation was whether the assets and liabilities that Leopold had generated in his years ruling CFS were personal to him or belonged to the state. Given that Belgium was taking over the state, its argument was that the law of state succession dictated that it was entitled to the assets. ${ }^{89}$ And that, according to the authorities cited by the Belgian lawyers, meant liabilities as well. ${ }^{90}$ Ultimately, in an agreement passed on January 28, 1911, the board members of the Foundation ${ }^{11}$ agreed

82. Edmund Morel, E.D. Morel's History of the Congo Reform Movement 194 (William Rogers Louis \& Jean Stengers eds., 1968) ("The immediate reason for the King's decision to hand his African domain over to Belgium was that the anti-Congo campaign in America threatened to catch fire.").

83. NZONGOLA-NTALAJA, supra note 35, at 266.

84. The fact that the sale was involuntary does not mean that Leopold had no claim-in effect, it simply meant that his claim was protected by a liability rule rather than a property rule. See Joseph Blocher \& Mitu Gulati, A Market for Sovereign Control, 66 DuKE L.J. 797, 803 (2017).

85. Harms, supra note 37 , at 344 ("Historians have generally depicted the Belgian government's takeover of the Congo in 1908 as a major blow to Leopold, but I will suggest that it may have been his grandest scheme of all. He managed to pawn off a bankrupt and debt-written colony onto the Belgian government while augmenting his personal fortune.”).

86. HOCHSCHILD, supra note 30 , at 259 (emphasis added).

87. Id.

88. Blocher \& Gulati, supra note 9, at 1246.

89. Cour d'appel de Bruxelles, supra note 76 , at 6.

90. The following three classic authorities on the Law of Nations are cited by the lawyer Eugène Hanssens: "The assets of states that cease to exist are actively and passively transferred to the successors of these states." (citing JOHANN CASPAR BLUNTSCHLI ET AL., LE DROIT INTERNATIONAL CODIFIÉ (1870)); "The successor continues the economic and fiscal personality of the abolished state, with its advantages and burdens." (citing Rivier); and "When a state has annexed itself with a foreign state, it takes on its account, if it can be expressed in this way, the active and passive debts of the annexed territory." (citing De Maertens). Cour d'appel de Bruxelles, supra note 76, at 42.

91. Amongst others was the Baron Auguste Goffinet. Goffinet was the executor of Leopold's 
to cede the securities to the Belgian government on the grounds that these securities had been acquired thanks in part to revenues generated by the CFS bonds which had by then been taken over by Belgium. ${ }^{92}$

For our purposes, what is important is that there appears to have been a clear understanding at the time of the litigation that the law of state succession dictated that the successor state took both assets and liabilities of the prior one. There is no indication that the Belgian lawyers thought any exception existed for odious debts akin to the kind of exception the Americans supposedly had created in 1898 after the Spanish-American war.

To quote the court filings by the Belgian government: " [] n international law there is no succession under the benefit of inventory. The inheriting state cannot establish as a condition that it accepts only those commitments that appear on the assets side. He must accept all the obligations and rights of the annexed state." 93 In sum, we find evidence that the law of state succession was thought to be strict, with no exceptions for odious debts.

To come at the question differently, one might ask whether there were any in the Belgian legislature or government who affirmatively did not wish for the state to take on Leopold's debts and what arguments they made. And there was indeed a faction that took this view-the leftist faction. In parliamentary debates, the socialist leader, Louis Bertrand, explicitly questioned the uses to which King Leopold had put the debts:

Note, gentlemen, and I insist on this point, because this is the essential purpose of our inquiry, that when the king dies and Belgium takes over the Congo, it is Belgium that will be responsible for these debts; it is we who will have to repay the millions borrowed without the current government having taken the slightest precaution to ensure that these new loans are justified or not! ${ }^{94}$

Again though, while we find explicit objections from within Belgium to the taking on of Leopold's debts, we find neither mention of any available exception to the law of state succession nor reference to the actions of the Americans in the negotiations with Spain roughly a decade prior. And that, to reiterate, is despite the fact that there was considerable discussion of whether Belgium was obliged to take on the Leopoldian debts.

The exception to the foregoing is the 1888 lottery loan, where there was some disagreement about whether the obligation should be taken on by the Belgian state. However, as we explain below, the disagreement had nothing to do with the odiousness of the borrower or the uses of the proceeds. In

will.

92. Cour d'appel de Bruxelles, supra note 76, at 22.

93. Id. at 368-69.

94. Annales Parlementaires [Parliamentary Annals], Chambre des représentants [House of Representatives], Feb. 28, 1905, at 816 (Belg.). 
1905, when the annexation of the Congo had first been suggested, the press and the world of finance ${ }^{95}$ signaled that they thought Belgium was bound to take on the debt.

The Belgian Finance Minister, represented by Hubert Van Neuss, ${ }^{96}$ however, held a different view. According to his analysis, when the Belgian government had allowed the bond to be floated, the then-Finance Minister, Auguste Beernaert, had clearly stressed that Belgium had no responsibility regarding this loan. ${ }^{77}$ When issued, some of the loan proceeds were set aside to build a portfolio ${ }^{98}$ which was managed by one of the issuing banks. ${ }^{99}$ The loan was thus complex ${ }^{100}$ because the payment of interest and amortization was guaranteed by the resources from this portfolio.

An internal memo ${ }^{101}$ questioned Belgium's responsibility regarding the 1888 lottery loan, since its reimbursement was supposed to be done through this special mechanism. The line of argumentation developed by the memo is straightforward: The funds set aside to guarantee the loan were sufficient, and the state had therefore no more responsibility for the loan. In other words, the portfolio was the loan's guarantee and the CFS (and Belgium even less so) bore no responsibility. Since the portfolio was managed by a board in which bankers had the majority (and thus the CFS only a minority), the CFS could not be held responsible for the loan. If the value of the portfolio was larger than the reimbursement, the contract stipulated that the CFS would receive the surplus but the contract did not explicitly state that the CFS should intervene if the portfolio's value ended up being too limited.

According to Van Neuss, this omission was purposeful. The CFS could not be held responsible for bad investments undertaken by the bankers. Van Neuss further argued that the lottery bond should be viewed as a lottery

95. The memo mentions the intervention of Fr. Roseels, a stockbroker.

96. In 1905 Hubert Van Neuss was General Secretary of the Belgian Minister of Finance, but he had previously been Head of the Finance Administration of the CFS, notably when the 1888 loan had been floated.

97. Annales Parlementaires [Parliamentary Annals], Chambre des représentants [House of Representatives], Apr. 27, 1887, at 296 (Belg.) ("On what grounds could one, on any occasion, in any case whatsoever, invoke an obligation, a guarantee, whatever? Could it be because of some stipulations of the securities of the loan? Of course not. It is the Congo Free State that will borrow and only it will be obliged to its lenders .... Subscribers, it has been said, will assume that a transaction authorised by a Belgian law must be controlled and guaranteed by Belgium. How, I ask, could they have such illusions? This warranty has been excluded in the most formal way.").

98. It seems it was possible to get information regarding the securities in which the proceeds had been invested. See JOURNAL DES FINANCES, May 24, 1902, at 4 (Belg.) for a list of these securities (mostly sovereign bonds but also municipal ones).

99. La Société Générale pour Favoriser L'Industrie Nationale Contract (Feb. 8, 1888) (on file in box 587 in the MinFin Oud files at the Archives Générales, du Royaume).

100. Other features of the lottery were quite uncommon, an element which according to the Journal des Finances could explain the limited success of the loan). See JOURNAL DES FINANCES, Oct. 4, 1904, at 4.

101. Situation Financière et Budget Colonial (undated) (on file in box 590 in the MinFin Oud files at the Archives Générales, du Royaume). 
rather than a bond, and that Belgium's obligation to take over the debt was doubtful. The press took over this argument in 1907,102 creating turmoil on the market and prompting Senator Albert Marquis de Beauffort to write to the Belgian Finance Minister to clarify the government's position. ${ }^{103}$ By 1907, the investments had proven profitable enough to render the discussion regarding the guarantee less pressing. ${ }^{104}$ This view was shared by the financial press. ${ }^{105}$

For the other loans, the general view was that Belgium would take over the debt. In 1903, the French newspaper Le Temps hinted at the possibility that someday the debt from the CFS might be transformed into Belgian state bonds should the Congo be annexed. ${ }^{106}$ Discussing the relative merits of the Belgian three percent perpetuity and the four percent 1901 CFS loan, a journalist from the Journal des Finances mentioned that should the Congo become a Belgian colony the four percent loan would be transformed into Belgian bonds. ${ }^{107}$ A little more than a year later, the newspaper stressed that even though the annexation law made a distinction between the debts from Belgium and the Belgian Congo, in fact Belgium was morally bound to guarantee the debts of the colony, an element which had led to a price increase for the Congo lottery bonds. ${ }^{108}$ In any case, all bonds but the 1888 lottery loan were listed as debts of the Belgian Congo in an internal memo of the Belgian Ministry of Finance from 1909.109

We have found only one source arguably suggesting that Belgium was not legally required to take on the CFS's debts. An August 22, 1908 story in the $W$ ashington Post reported that holders of Congolese debt had argued that "[s]hould insolvency develop" in the new colony, Belgium "although not responsible in principle, would be bound morally to stand sponsor for the Congo." 110 But there is no explanation here for those words "although not responsible in principle." More importantly, there is no indication of any odious debts type exception, particularly given the words that Belgium was "bound morally to stand sponsor" — an odious debt doctrine would point

102. With articles published in Le Patriote and Le Petit Bleu in December 1907. Archives Générales, supra note 43 (on file in box 590 in the MinFin Oud files at the Archives Générales, du Royaume).

103. Memorandum from Senator Albert Marquis de Beauffort to Finance Minister (on file in box 590 in the MinFin Oud files at the Archives Générales, du Royaume).

104. Fonds d'Amortissement de L'Emprunt à lot de l'E.I. (on file in box 590 in the MinFin Oud files at the Archives Générales, du Royaume).

105. Petite Correspondance, JOURNAL DES FINANCES, June 20, 1908, at 596.

106. Discussing the merits of the bonds from the CFS the journalist concludes "and we do not even consider the possibility of converting the debt of the Congo Free State into a Belgian one if one day the Congo were to belong to it." LE TEMPS, Jan. 26, 1903 (author translation).

107. Notes et Arbitrages, JOURNAL DES FINANCES, June 1, 1907, at 506.

108. Notes et Arbitrages, JOURNAL DES FINANCES, Oct. 24, 1908, at 1011.

109. Intérêts de la Dette du Congo Belge Échus au 30 Juin 1909 (June 30, 1909) (on file in box 591 in the MinFin Oud files at the Archives Générales, du Royaume).

110. Congo Deficit Likely. Belgium Bound Morally to Stand Sponsor. Securities' Holders May Sue, WASH. PosT, Aug. 22, 1908 (emphasis added). 
the moral calculus in the opposite direction.

We have also found a few broad references to Belgium's moral and political obligations to take on and remedy the ills of Leopold's actions in the CFS. But on our reading, these are not about the debt, and definitely not about legal obligations.

A 1906 book by the Jesuit writer Arthur Vermeersch urged:

Although officially we do not have to answer for the treatment meted out to the Congo natives, our honour and the good name of Belgium are at stake if a country which is governed by our King and largely administered by Belgians, is not worthy of the esteem and confidence of civilized humanity. ${ }^{111}$

A century later, Hochschild reached a similar conclusion: "Oddly enough, Leopold had the Belgian government cornered. The Congo reform movement had reached such a pitch of fervor that Belgium's international reputation was at stake."112 Consider also Arthur Conan Doyle, who was active in the Congo Reform Association:

The Congo State was founded by the Belgian King, and exploited by Belgian capital, Belgian soldiers and Belgian concessionaires. It was defended and upheld by successive Belgian Governments, who did all they could to discourage the Reformers. In spite of legal quibbles, it is an insult to common sense to suppose that the responsibility for the Congo has not always rested with Belgium. The Belgian machinery was always ready to help and defend the State, but never to hold it in control and restrain it from crime. ${ }^{113}$

Doyle, for his part, took this argument to its natural conclusion and argued that Belgium was unfit to rule the Congo, and that its culpability for Leopold's misdeeds should not be transmuted into ownership. ${ }^{114}$

Reputation is not the only possible non-legal explanation for why Belgium took on the debt. Maybe there was a fear that unhappy creditors in countries like Britain and France would join cause with human rights crusaders in persuading their governments to seize the CFS for themselves. Hochschild writes that "if Belgium didn't take over the colony soon, some powerful country might: France and Germany, long jealous of the King's lucrative rubber profits, had their eye on pieces of Congo territory." 115

111. AsCHERSON, supra note 36, at 258 (quoting Vermeesch's book, and saying that it was "widely-read")

112. HOCHSCHILD, supra note 30 , at 257-58.

113. A. Conan Doyle, The Crime of the Congo, at vii (1909); id. at viii ("When Belgium took over the Congo State, she took over its history and its responsibilities also.").

114. Id. at 123

115. HoCHSCHILD, supra note 30, at 257-58. 
Indeed, E.D. Morel, leader of the Congo Reform Association, had once advocated a division of the CFS between Britain, France, and Germany (though he would later reconcile himself to the Belgian Solution). ${ }^{116}$ Still, the historical record does not provide much support for the notion that Belgium felt compelled to take on the debts because of a fear of gunboat diplomacy.

Another sticking point with the transfer of the CFS's liabilities and control from Leopold to the Belgian state was Leopold's effort to retain control of crucial portions of the Free State. Specifically, he tried to retain ownership of the Domaine la Couronne - the crown domain that Leopold had long insisted was necessary to make Congo financially viable, and which he now wanted to deny to Belgium. ${ }^{117}$ Attacks on the treaty primarily focused on ownership of the Domaine rather than the debts. ${ }^{118}$ According to historian S.J.S. Cookey:

The treaty itself only seemed to confirm the fears of the reformers [that Leopold would retain control of the revenues of the Domaine]. The main provision of its four Articles was to transfer the Congo to Belgium with all its assets and liabilities together with an obligation to maintain all the rights of third parties. ${ }^{119}$

The New York Times denounced this "trick," saying: "In other words, Leopold transfers from his right hand to his left hand the domain which he has exploited as private property." 120

Another explanation with regard to the financial aspects of the annexation of the Congo was raised by members of the Parti Ouvrier Belge in 1908. Jules Destrée accused the members of the right-wing parties of acting in self-interest because they had substantial investments in the Congo. ${ }^{21}$ The Belgian socialist newspaper, Le Peuple, even published a list of MPs involved in these investments. ${ }^{122}$ According to the socialist leader,

116. MOREL, supra 82, at 182; HOCHSCHILD, supra note 30, at 257-58 (explaining how Morel came to accept the solution of converting the Congo into a Belgian colony).

117. Belgium Votes to Annex Congo. Deputies Still Refuse to Guarantee Payment of Interest on Congo Debt., N.Y. TIMES, Aug. 21, 1908 ("The situation regarding annexation of the Congo independent State was thrown into great confusion last year by the action of King Leopold in withdrawing the control over the Crown domain, the richest part of the Congo, from the regular Congo administration, in order to prevent the passing of the domain to Belgium should annexation be consummated."). The crown domain — held by the Fondation de la Couronne — was an issue of overwhelming importance in the 1907 negotiations; so much so that it overshadowed the question of how Belgium would actually govern its new colony. ANSTEY, supra note 47, at 18. The King ultimately backed down on this demand, in return inter alia for Belgium's agreement to take on the colony's debts. S.J.S. COOKEY, BRITAIN AND THE CONGO QUESTION, 1885-1913, at 212 (1968).

118. COOKEY, supra note 117, at 212.

119. Id. at 204.

120. Fury Caused by Leopold's Trick. His New Congo Scheme Arouses Bitter Opposition in Belgium. Britain is Urged to Act, N.Y. Times, Sept. 15, 1907.

121. Annales Parlementaires [Parliamentary Annals], Chambre des représentants [House of Representatives], June 18, 1908 (Belg.).

122. Ceux pour qui le Congo est une Bonne Affaire: La Part des Politicians Bourgeois, LE PEUPLE (Belg.). 
taking over the debts of the CFS would guarantee that no one would question the concessions made to private firms. ${ }^{123}$

As at Berlin in 1885, when Leopold took ownership of the CFS, the real party in interest was absent from the negotiations: the Congolese who would ultimately foot the bill. ${ }^{124}$ This was in part a result of Belgium's own domestic politics: the government was "bound by their promises to the Belgian tax-payer that annexation would impose no financial burden." 125 Jules Renkin, the first-ever Belgian Minister of Colonies (he took office in October 1908, just before the transfer), told the British Foreign Office that service of the colonial loans would technically be the colony's responsibility, but that it would eventually be covered by a Belgian grant-in-aid.126

In practice, the Congolese were made-with no say in the matter-to pay for their own transfer from one colonial master to another. ${ }^{127}$ Compounding the perversity, much of the purchase price ended up back in Belgium, as Leopold poured funds into construction projects, museums, and the like, burnishing his own legacy while the Congolese were saddled with the debt. In a scathing article, Morel wrote sarcastically of the Congolese living in the crown domain, "the natives who have the privilege of being enslaved in this particular area, will have the honour of contributing substantial sums to the Civil List of future Belgian monarchs and their offspring." 128

The Congo Reform Association (C.R.A.) was not hoodwinked, as its members "attached the greatest importance to this question of finance, which they regarded as the test by which the intentions of the Belgian

123. Annales Parlementaires, supra note 121, at 31 ("The interest of the concessionary companies in Belgium taking over the succession of the Congo Free State is not debatable .... If Belgium assumes, as regular and valid, the obligations of the Congo Free State, the interests of the companies are fully insured.").

124. HochsCHILD, supra note 30, at 259 ("Those funds were not expected to come from the Belgian taxpayer. They were to be extracted from the Congo itself.'); see also PAKENHAM, supra note 42, at 662 ("On these modest terms - that would cost the Africans of the Congo ninety-five million francs (L3.8 million) - the King agreed to hand over the whole Congo, lock, stock, and barrel, to little Belgium.").

125. COOKEY, supra note 117, at 223-24.

126. Id. at 261 (emphasis added).

127. LeWis H. Gann \& Peter Duignan, The Rulers of Belgian Africa 1884-1914, at 151 (1979) (“The Congolese taxpayer was left with responsibility not only for the Free State's debt of 110 million francs but also for a 'gratitude fund' given to the king "in testimony for his great sacrifice in favor of the Congo created by him,' as well as for another 40 million francs for the so-called Niederfülbach Foundation, one of the king's financial instruments, which was ultimately transferred to the Belgian state in 1923."); Steven Johnson, King Leopold II's Exploitation of the Congo From 1885 to 1908 and Its Consequences 70 (2014) (unpublished thesis, University of Central Florida), http://stars.library.ucf.edu/

honorstheses1990-2015/1642/ ("Instead of cancelling the debt that was amassed forcefully and unethically, Belgium only sought to increase the Congo Free State's debt which added to the taxation burden during the Great Depression.”).

128. E.D. Morel, The Congo Cession: What the New Treaty Means, MANCHESTER GuARDiAn, Dec. 17,1907 , at 6 . 
government as a whole must be judged." 129 In the words of a 1909 C.R.A. memo to the British Foreign Office:

[T]he Belgian Government, alone among Governments of Christendom, claims the right to govern a tropical dependency in Africa by means of enormous taxes wrung from its inhabitants, and by the issue of loans, the interest upon which it expects African subjects to pay, and caps this claim by demanding of these same African subjects that they shall provide subsidies for the Belgian heir-apparent and his sister, for ex-officials, for missionary societies, medical and philanthropic institutions in Belgium, that they shall provide for the upkeep of museums, institutes, and tropical greenhouses in Belgium and that they shall even pay the salaries of the governing body of the Congo in Brussels and the cost of newspapers and periodicals, presumably intended for the edification of the members of that body. ${ }^{130}$

\section{WAS THE CONGO FreE StATE'S DeBT Odious?}

There is little doubt that King Leopold's governance of the CFS was odious in a literal sense. To the degree that Leopold's despotism is even debated, the questions tend to be about Belgium's role and responsibility, ${ }^{131}$ or just how many millions of people were killed as a result of his rule, or whether it amounted to genocide. ${ }^{132}$ The question for our purposes is whether his debts were odious as a legal matter, under the relevant laws, assuming that such a doctrine was recognized at the time.

In the most commonly articulated version of the odious debts doctrine, 133 there are three questions that have to be answered in the affirmative before a debt can be deemed odious and repudiated. First, to what extent was the borrowing done in a personal sense; that is, did the leader or government have the consent of the populace in this particular case? Second, were the proceeds used largely (or in some articulations of the doctrine, exclusively) for the benefit of the leader? And third, did the

129. COOKEY, supra note 117 , at 259.

130. Id. at 259 (quoting C.R.A. to F.A., Nov. 17, 1909, FO 403/409).

131. See, e.g., Raf Casert, Belgian Africa Museum to Take a More Nuanced Look at Colonial Past, CHRISTIAN SCI. MONITOR (Dec. 5, 2018).

132. See, e.g., HochSCHILD, supra note 30, at 225-34 (discussing attempts to calculate deaths in the CFS); REYBROUCK, supra note 47, at 95 (arguing that it would be "absurd in this context to speak of an act of 'genocide' or a 'holocaust'," since there was no intention to exterminate).

133. The most frequently invoked definition of the doctrine comes from the writings of a Russian jurist, Alexander Nahum Sack in 1927. Sack, who advocated a narrow definition of the doctrine, would have required all three elements of his definition to be satisfied for a debt to be deemed odious. ALEXANDER NAHUM SACK, LES EFFETS DES TRANSFORMATIONS DES ÉTATS SUR LEURS DETTES PubliQues ET Autres Obligations FinANCIÈRES (1927); see also Buchheit et al., supra note 2, at 1218-19 (discussing the Sackian definition). 
creditors know that their funds were going to benefit the leader personally rather than the populace in whose name the borrowing was officially being done?

We find that all three conditions were met, which makes it all the more notable that the doctrine was never invoked.

\section{A. Absence of Consent}

The first part of the traditional odious debt definition requires that the debt be taken on in the name of a sovereign, but without the consent of the people. Although the unusual status of the CFS as a personal colony raises some wrinkles, this factor seems satisfied.

The debt contracts make it clear that Leopold represented to creditors that he was acting as the sovereign of the CFS. For example, Leopold signed the 1888 bonds as sovereign, not in his individual capacity. The debts were made in the name of the CFS and the payment procedures (matters such as the administration of the sinking fund) were placed in the hands of the government of the CFS.134 Internal memos from the Belgian Finance Minister confirm this interpretation. While discussing the listing of the 1888 loan on Belgian exchanges and the stamp duty to be paid, the Belgian Finance Minister noted that "the exemption from stamp duty is easily justified, although de facto established in Brussels, the government of the CFS is none the less completely independent" 135 The Committee created by the Belgian Senate to examine the loan issue concurred: " $[\mathrm{T}] \mathrm{t}$ is therefore necessary to treat the securities created by it [the CFS] in Brussels as foreign securities."136

The traditional odious debt analysis focuses on whether debts should be considered personal to a leader, as opposed to those of the state. That division is complicated in cases of "personal" sovereignty. ${ }^{137}$ To the degree that Leopold was both king and the owner of the CFS, it may be hard to draw a line between debts he contracted on behalf of the CFS and those he took on personally. ${ }^{138}$

But from the perspective of the odious debts doctrine, those conceptual

134. Despite the fact that there was no ambiguity in the contract, some investors asserted the existence of a Belgian guarantee for the 1888 loan even though no such guarantee existed in the contract. See Advertisement from the International Securities Syndicate, London (on file in box 587 in the MinFin Oud files at the Archives Générales, du Royaume).

135. Archives Générales, supra note 43 (on file in box 587 in the MinFin Oud files at the Archives Générales, du Royaume).

136. Annales Parlementaires [Parliamentary Annals], Chambre des représentants [House of Representatives], Apr. 27, 1887 (Belg.).

137. See generally PRESS, supra note 53 (describing other such personal sovereignties).

138. MOREL, supra note 82, at 45 ("The very word 'State' used in describing an organisation such as this was palpably a misnomer, a fiction and subterfuge. What, in Heaven's name, was the 'Congo Free State? It was no State.”). 
difficulties can largely be sidestepped - the relevant question is whether the debts were contracted with the consent or for the benefit of the Congolese people. It is clear that they were not. And, in fact, Leopold's personal ownership of the colony all but guaranteed as much, as it lacked even the limited transparency or responsiveness that one might find in other African colonies. ${ }^{139}$

\section{B. Absence of Benefit}

As to the second element-absence of benefit to the people burdened by the debt- there should likewise be little need for discussion. Far from benefitting from the revenue that Leopold raised through his bond issuances, the Congolese were subjected to further oppression, as he used the funds to set up the Force Publique and other infrastructures of despotism. It would be one kind of wrong to extract, by the lash, money to be used for the development of the territory itself. Instead, the wealth of the CFS was sent to Belgium, with nothing of significance sent back in return. ${ }^{140}$

Although there can be no question that the Congolese did not benefit from the Congo's riches, there is debate about who did. Belgian scholar Jean Stengers argues that Leopold himself was actually not the primary beneficiary. He points out that "[i]n King Leopold's lifetime, no proof was ever offered that the Congo had allowed him to add to his personal wealth," though admittedly "the circumstantial evidence seemed very strong indeed." 141 Stengers concludes that "King Leopold extracted money from the Congo, but used it almost exclusively to enrich the [Belgian] national

139. In that sense, history might have turned out better if the Belgians had more of a colonial appetite. See V. Lovett Cameron, Chartered Companies in Africa, 15 NAT'L REV. 464 (1890); see also PRESS, supra note 53, at 248 (" $[\mathrm{H}]$ istory would have looked different had there been a public check on the King of the Belgians' power early on, if for no other reason than that more parties would have demanded a slice of profits and thus diluted his authority."); REYBROUCK, supra note 47, at 57 ("Kaiser William I, Queen Victoria, and Jules Grévy, president of France's Third Republic, also ruled over vast stretches of Africa in 1885, but none of them owned those areas personally. Their colonial policies were not a private matter but a government affair, watched over by parliament (chamber of deputies) and cabinet. But the Belgian king ruled over the new state in a personal capacity.").

140. NZONGOLA-NTALAJA, supra note 35, at 20 ("As a good capitalist, the king had to judge the success of his colonial enterprise in strictly business terms, that is, in terms of whether or not it was profitable .... This meant the use of torture, murder and other inhumane methods to compel the Congolese to abandon their way of life to produce or do whatever the colonial state required of them."); PAKENHAM, supra note 42, at 588 ("Should Leopold re-invest this profit in the Congo, according to the unwritten code practised in colonies elsewhere, to benefit both the natives and European investors? Leopold saw no reason why it should .... He had put his fortune in the Congo. Now he intended to reap the benefit, repaying himself and enjoying the profits."). Even Reybrouck's somewhat more sympathetic account suggests only that Belgium, rather than Leopold—but certainly not Congo itselfprofited. REYBROUCK, supra note 47, at 61 ("The revenues for which he hoped were not meant to develop the Free State, but to be funneled off to Brussels .... Leopold used one of his states, Congo, to provide the other, Belgium, with new élan.").

141. MOREL, supra note 82, at 269. 
heritage by acquisitions of property, by monumental constructions, and by works of urbanization. His obsession was not with his own fortune but with the embellishment of his country." 142

Other critics, both in Belgium and elsewhere, argued to the contrary that the King was personally enriching himself through the colony. In 1906, Félicien Cattier's Etude sur la Situation de L'Etat Indépendent du Congo summed up this view:

[T] he clear and indisputable truth . . . is that the Congo State . . is not a colonising state, it is barely a state at all: it is a financial enterprise. The colony has been administered neither in the interests of the natives nor even in the economic interest of Belgium: to obtain for the King-Sovereign a maximum of resources, this has been the objective of governmental activity. ${ }^{143}$

Cattier was primarily concerned with the King's abuse of his position for personal profit, not with the human rights abuses in the Congo. ${ }^{144}$ As he put it, the CFS was "not a colonial power" but "a financial enterprise . . . administered neither in the interests of the indigenous people nor even in the interests of Belgium [but] for the benefit of the King-Sovereign."145 Despite (or perhaps because of) its bloodlessness, Cattier's report had a powerful impact in Belgium. ${ }^{146}$

Cattier noted that "[a]gain and again, when reforms [in the Congo] were demanded, the Congo State . . invoked its poverty as a reason for not implementing them. Its budget is permanently in deficit while millions which belong to it are wasted in Belgium on luxury works, on suborning people, on shady and obscure deals." 147 Cattier calculated that Leopold had, on behalf of the Congo, borrowed more than 130 million francs, not including the tens of millions from Belgium itself, and earned 70 or 80 million francs from rubber alone-all measured against an actual budgetary

142. Id. at 243 .

143. EWANS, supra note 50, at 217 (translating Félicien Cattier's Etude sur la Situation de L'Etat Indépendent du Congo).

144. Just ten years earlier, Cattier had written a positive account of the CFS's humanitarian progress. Félicien Cattier, L'Etat Indépendant du Congo et les Indigénes, 27 RevUE DE DROIT INTERNATIONAL ET DE LEGISLATION COMPARÉE 263 (1895).

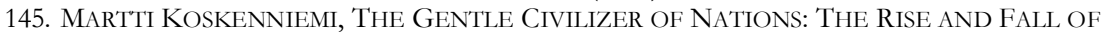
INTERNATIONAL LAW 1870-1960, at 160, 165 (2002) (quoting Cattier's argument).

146. ANSTEY, supra note 47, at 15; KOSKENNIEMI, supra note 145, at 160 (concluding that the report "created a shock in Belgian political milieus and contributed significantly to the transformation of attitudes in favor of immediate annexation").

147. EWANS, supra note 50, at 216. Boulger's fawning biography of Leopold emphasizes that the CFS's "gravest responsibility" was eradication of the slave trade, and goes on to emphasize that " $t]$ he task before the Congo State was immense, and when its slender resources are borne in mind the courage and confidence with which it entered upon the struggle must be pronounced remarkable." 1 BOULGER, supra note 55, at 188. Others argue to the contrary that "Leopold II directly encouraged slave raids." NZONGOLA-NTALAJA, supra note 35, at 20-21 (internal citation omitted). 
deficit of just 27 million from 1892 to 1905.148

As for the balance, Leopold insisted that he had not gotten a penny from his humanitarian works in the Congo. ${ }^{149}$ But it was eventually discovered that he had gotten a great deal, much of which went to the purchase of more than one hundred properties in Belgium, along with as much as 65 million francs spent on his palace at Laeken, the Arcade $d u$ Cinquantenaire, and the Museum at Tervuren. ${ }^{150}$ Cattier concluded that on one representative occasion, the King borrowed 5.2 million Francs to pay a 1.08 million Franc deficit, and that the remainder wound up in the King's pocket. ${ }^{151}$ One scholar estimates that Leopold earned $\$ 1.1$ billion from the Congo during his lifetime. ${ }^{152}$

Leopold's use of CFS-related funds was the subject of public debate in Belgium in the years leading up to the annexation, as political leaders discussed the degree to which Congolese debts could be used to finance Leopold's pet projects and whose responsibility should ultimately be borne by the Belgian people. In practice, this would mean the Congolese, but that is not how it was discussed. Those debates, which we have located in parliamentary and court records, provide a window into the popular and political understanding of state succession. But we do not see any invocations of the odious debt exception, even by those who criticized Leopold and his spending most harshly.

In 1904, the socialist Louis Bertrand published an article questioning the uses made of the funds, including the acquisition of real estate in Brussels and in Ostende worth several million Belgian francs. He challenged the legitimacy of these uses if the Belgian taxpayer was eventually to foot the bill:

If it was with his money that the king carried out all this work, we would have nothing to say. but if on the contrary it is with the millions borrowed by the state of Congo, and which finally will have to be paid by the Belgian taxpayers that these expenses are made, it is necessary to shout at the daredevil. It is even ensured that the lucky contractors of the works of Laeken Tervuren etc. ... are often paid in bond $[\mathrm{s}]$ of the State of Congo and this at a rate much lower

148. EWANS, supra note 50, at 216.

149. Id. at 226.

150. Id. at 216. It is hard to pin down the exact accounting, but similar expenditures are reported in PAKENHAM, supra note 42, at 587; JOHN READER, AFriCA: A BIOGRAPHY OF THE CONTINENT 575 (1997) (outlining the different public works projects in Belgium that King Leopold funded using profits from the Congo); REYBROUCK, supra note 47, at 88 (describing the public works in Belgium developed with money from the CFS); and Harms, supra note 37, at 346 (describing bond distribution and depicting King Leopold's own bond).

151. PAKENHAM, supra note 42, at 657 (citing Cattier).

152. HOCHSCHILD, supra note 30, at 277 (citing Marchal's "conservative" estimate). 
than that quoted on the stock exchange. ${ }^{153}$

Denouncing the newspapers presenting Leopold II as a generous king, Bertrand went on:

If Leopold II is generous with the money borrowed by the State of Congo and which Belgium will have to repay - we insist on this point - he is generous at a low cost, because he is generous with the money of all of us. ${ }^{154}$

A year later in Parliament, Bertrand reiterated his attack:

What is the purpose of these millions then? They are used, gentlemen, to satisfy royal fantasies and it is useful, at this moment, to mention some expenses made for some time by the king, expenses of which the press makes great noise, by praising the generosity of the sovereign! As everyone knows, in recent years, the sovereign of the Congo Free State has made considerable expenses. ${ }^{155}$

He went on to detail various buildings, roads, villas, improvements to the palace at Laeken, a new colonial palace, and purchases abroad, including in the South of France:

Until now, these purchases have been made on behalf of the domain of the Congo free State; this is how they appear in the deeds of transfer and in the land register.... We also know that the State of Congo has taken an interest in various cases of pure speculation and in other very random cases, such as the famous Chinese railway, for example. How many millions have been spent on it? We don't know that. What we know, I repeat, is that these are extraordinary expenses made with the money borrowed by the Congo Free State and for which Belgian taxpayers will have to pay the charges when Belgium takes over the Congo or when the king dies. 156

The socialist leader further asserted that contracts for public works were paid to some entrepreneurs without public tender. These entrepreneurs were lavishly paid because part of the payment was made with CFS bonds that bankers did not want. ${ }^{157}$ Bertrand concluded:

These millions, I repeat, are not spent in Congo, but almost

153. Bertrand Louis, La Belgique et le Congo. La Danse des Millions, LE PEuPLE, Oct. 19, 1904 (Belg.). 154. Id.

155. Annales Parlementaires [Parliamentary Annals], Chambre des représentants [House of Representatives], Feb. 28, 1905, at 816-17 (Belg.).

156. Id.

157. Id. at 817 . 
exclusively in Belgium; they are spent on sumptuous works and it is the Belgian taxpayer who will one day be responsible for paying this huge debt, the proceeds of which are thus wasted!158

Again, and despite the harsh critique of how the Leopoldian loans were being used, the assumption was clearly that Belgium would have to take on Leopold's debts. The reply of the Belgian Finance Minister, Paul Joseph de Smet de Naeyer, is not exactly convincing:

The State of Congo is building, at its own expense, the Tervueren Museum, its outbuildings and the training establishments that will be annexed to it. These expenses, made in Belgium, have their equivalent value now acquired in our country. The State of Congo also bears the costs of the colonial garden of Laeken, which provides it with undeniable services. ${ }^{159}$

One is left wondering how the colonial garden of Laeken was providing "undeniable services" to the CFS.

The use of CFS bonds to pay directly for works carried out in Belgium was reaffirmed in the framework of the trial related to Leopold's succession. According to Eugène Hanssens, lawyer for the government, 10,000 bonds from the four percent 1901 issue had been directly given to the entrepreneur Wauters-Dustin in payment for works undertaken in Laeken and Tervueren with other CFS bonds being used for expenses elsewhere. ${ }^{160}$

The Belgian government was aware of this fact:

It goes without saying that immediately after the present dispute arose, the government took care to question all those who, because of their situation, were in a position to inform it of the situation regarding the 1901 and 1904 loans. In particular, he heard Baron Van Eetvelde, Baron Aug. Goffinet, M. Liebrecht and M. H. Pochez. And all acknowledged that these loans were used almost entirely for non-Congolese purposes, adding that it could not be otherwise, since the Congo has consistently given surpluses of revenue each year since before 1901.

Baron Van Eetvelde provided this precise and particularly interesting information. Having pointed out to the king that the allocation of Congo's resources for purposes other than his own was not regular, the King replied that it was necessary to take advantage of Congo's prosperity to constitute "a war chest" and that

158. Id.

159. Id.

160. Cour d'appel de Bruxelles, supra note 76, at 134-35. 
this "war chest" was supplied by the 1901 and 1904 loans. ${ }^{161}$

Emile Vandervelde was even more explicit in linking directly the atrocities made in the Congo and the fact that the loans were used to develop the king's pet projects in Belgium, amongst other the Arcade du Cinquantenaire, a monumental triple arch in Brussels:

Ah! Gentlemen, this is a morally impossible situation. I understand that we are for or against colonial policy, for or against the immediate annexation of Congo, but you have no courage to be either for or against; you persist at an altitude that is not one; you allow an exotic autocracy to grow stronger in our constitutional country, encroaching more and more on the rights of parliament; you abandon to royalty means of action independent of any parliamentary intervention; you promise the Belgian people the crumbs of your table; you build monumental arcades, which one day may be called the arcades of cut hands. ${ }^{162}$

The relationship between markets and governance was central to the debate about the CFS. Some of Leopold's most prominent critics highlighted what might be thought of as the market orientation of the CFS. In Roger Casement's assessment, "[t]he root of the evil lies in the fact that the government of the Congo is above all a commercial trust, that everything is orientated towards commercial gain." 163 This commercial orientation effectively guided the hands that administered the lashes: "The praiseworthy official would be he whose district yielded the best and biggest supply of the commodity; and, succeeding in this, the means whereby he brought about the enhanced value of that yield would not, it may be believed, be too closely scrutinised." 164

For Morel, the problem was not exactly the commercial orientation, but the failure to secure and honor the property rights of the Congolese. In other words, he did not necessarily disagree with King Leopold that the CFS was property — he simply thought that the King was not its rightful owner:

The wrong done to the Congo peoples originates from the substitution of commerce which is based upon the recognition by Europe of native ownership in land and in the produce of the land (which the native alone can gather), with the consequent onus upon

161. Id. at 139

162. Annales Parlementaires [Parliamentary Annals], Chambre des représentants [House of Representatives], Feb. 28, 1905, at 821 (Belg.).

163. EWANS, supra note 50, at 193; see also PAKENHAM, supra note 42, at 661 (quoting the U.S. Consul-General, Smith, whose report "might have been drafted by Casement himself," saying that the Congo state was not really a state but "one tremendous commercial organization").

164. EWANS, supra note 50, at 198. 
the European to PURCHASE that produce which modern industrialism requires, by a system based upon the right of a European State to expropriate the Native of tropical Africa from his land and from the produce of the land (which produce constitutes in tropical Africa the element of commerce), with the consequent elimination of the onus upon the European to PURCHASE produce which has ceased to belong to the gatherer of it. 165

What is notable about this is not just Morel's recognition of the fact that the natives were being pillaged. Rather, it was his claim that Leopold's property-like interest in the Congo was the cause — not a symptom-of the atrocities:

To denounce the cruelties inflicted upon the native population was a mere beating of the air, while the basic cause of the cruelties remained unchallenged. So long as King Leopold's claim to dispossess his African subjects of the natural wealth of the country on the ground that it was his, was not contested, the foundations of his system could weather every assault. 166

A statement made by Georges Lorand summarizes the position of part of the opposition: "Congo has so far brought coffins to the country and dividends to the king and to men of finance his associates." 167 Whatever the number of coffins, and whoever received the dividends, it is clear that the benefits of the loans did not flow to the Congolese people. The second factor of the odious debts definition, too, is satisfied.

\section{Creditor Knowledge}

Of the three elements of the traditional odious debt doctrine, the one about which we have the least information is the final one regarding creditor knowledge of what conditions they were lending into. In order for the CFS's debts to qualify for the odious debts exception (assuming that it existed), creditors must have known, or should have known, that Leopold was

165. COOKEY, supra note 117, at 129 (quoting passage from EDMUND D. MOREL, KING LEOPOLD'S RULE IN AFRICA (1904)).

166. MOREL, supra note 82 , at 66 . He was also the first to note that he was the first to note this: "I was the first to show the inseperable connection between immoral economics and personal cruelty, the everlasting (and I doubt not, wearisome) preacher of the truth that to rob the native of tropical Western African of his trading rights in the produce of his soil is to rob him of his liberty and to destroy him." Id. at 138.

167. "Le Congo a rapporté jusqu'ici des cercueils au pays et des dividendes au Roi et aux financiers ses associés." Annales Parlementaires [Parliamentary Annals], Chambre des représentants [House of Representatives], June 19, 1908, at 179 (Belg.). 
borrowing for his personal benefit. 168

The issue actually breaks down into two sets of questions: One about the doctrine's applicability, and the other about its existence. To show that the odious debts exception applied to any particular creditor, the question is who knew what, and when, about Leopold's misbehavior in the CFS. The answer here likely varies, depending on when the debts in question were contracted. Perhaps the lenders in the original 1888 loan thought Leopold was engaged in a humanitarian enterprise. But Leopold not only was unable to sell all of that initial bond issue (about half the bonds went unsold), he continued to have to borrow for many years after. As described above, ${ }^{169}$ Leopold was using unissued bonds from the CFS's failed issuances to pay a variety of his obligations all the way up to his removal from power in 1908.

For purposes of our inquiry, however-whether the odious debt doctrine was thought to exist - the threshold is different. If the doctrine was even arguably applicable to Leopold's creditors, then one would expect to see it discussed. After all, vast sums of money were at stake, and the acts that rendered those debts arguably odious were prominent in public discourse. Silence regarding the doctrine's applicability to the facts would appear to be evidence that the doctrine did not exist at all.

Admittedly, it is hard to sift through the silences, in part because Leopold worked hard to obscure from the public what was really going on in the CFS. ${ }^{170}$ Where atrocities could not be denied, he blamed the individuals involved, rather than the administration as a whole. ${ }^{171}$

Given some people's willingness to believe-or pretend to believethat the Congo was being administered with regard to the highest humanitarian ideals, this was probably sufficient to keep many in the dark in the early years of Leopold's rule. Indeed, "at the time the rape and pillage of the prostrate land continued with much approbation from the world at large[,] Leopold was even elected president of the (British) Aborigines' Protection Society." 172

That message stayed constant during the first few years of the CFS, as Leopold scrambled for financing. In Doyle's assessment:

During these years-from 1890 to 1895-whatever indignation might be felt among traders over the restrictions placed upon them,

168. Precisely what level of knowledge is required, and whether the standard should be subjective (thus protecting deceived creditors) or objective (covering those who should have known) is a contested question. See, e.g., Christoph G. Paulus, "Odious Debts" vs. Debt Trap: A Realistic Help?, 31 BROOK. J. INT'L L. 83, 94-95 (2005) (critiquing both the subjective and objective tests).

169. See supra Section I.A.

170. Annales Parlementaires [Parliamentary Annals], Chambre des représentants [House of Representatives], June 19, 1908, at 69 (Belg.).

171. MOREL, supra note 82 , at 175.

172. Michael Deibert, The Democratic Republic of Congo: Between Hope and DESPAIR 14 (2013). 
the only news received by the general public from the CFS concerned the founding of new stations, and the idea prevailed that King Leopold's enterprise was indeed working out upon the humanitarian lines which had been originally planned. ${ }^{173}$

Morel himself wrote that in the late 1890s, "[o]ver the Congo itself there hung a dense fog of mystery." 174

But that fog was eventually penetrated. Reports from the Congo began to filter back as early as the 1880s. ${ }^{175}$ Perhaps the earliest and most prominent critiques came from missionaries, including George Washington Williams, a black missionary from the United States who began to draw attention to the CFS as early as $1890 .{ }^{176}$ Historian John Hope Franklin writes of Williams: "It is his testimony that brought to the world the first detailed account of King Leopold's holocaust of the Congolese people, atrocities that Williams himself characterized as "crimes against humanity."'177 William Sheppard, another black American missionary, played a similar role. ${ }^{178}$

Throughout the early 1890s, reports mounted in the British press, to the point that by 1897 the CFS felt it necessary to issue a memorandum defending its position. ${ }^{179}$ Doyle, noting the "shame" of the European nations who failed to take action, pointed to a chain of available sources from beginning in the mid 1890s: "In showing the continuity of the Congo horror and the extent of its duration (an extent which is the shame of the great Powers who acquiesced in it by their silence), I have marshalled witnesses in their successive order. Messrs. Glave, Murphy and Sjoblom have covered the time from 1894 to 1897; Mr. Clark has carried it on to

173. DOYLE, supra note 113, at 16.

174. MOREL, supra note 82, at 52. Of course, this was Morel's own account, and he had every reason to suggest that his activities and those of the Congo Reform Association were responsible for lifting that fog. "From this survey, one central fact of capital importance stood out-in gold relief. Public Opinion had not grasped that the occurrences reported from the Congo were the inevitable results of a fixed policy, carefully thought out, deliberately planned, immovable as the Pyramids .... This capital feature in the case was not, and could not be apprehended because the material was lacking. The problem for me then was simply this. Had I the necessary qualifications to so present the case in writing and in speech as to bring conviction to men's minds: and what was the best way to set about it?" Id. at 58 .

175. COOKEY, supra note 117, at 35 ("As early as 1888 British humanitarians had attacked the ruthlessness which Stanley, as agent of the Congo State ... had shown at Stanley Falls in conniving at the plunder and destruction of African villages and recruiting slaves as carriers .... The public, unlike the Foreign Office, were in no doubt as to the right and obligation of Britain to intervene officially in the Congo State.").

176. See generally John Hope Franklin, GeOrge Washington Williams: A Biography 207-08 (Duke Univ. Press 1998) (1985) (“[Williams'] reports seemed to be generally accessible both in Europe and the United States ... by 1890.”).

177. NZONGOLA-NTALAJA, supra note 35 , at 23.

178. See generally William E. Phipps, William Sheppard: Congo's AFrican American LIVINGSTONE 144 (2002) (“Sheppard's eyewitness account of eighty-one severed and smoked hands was the most widely quoted information about Congo atrocities.").

179. COOKEY, supra note 117 , at 36-44. 
1900, we have the deeds of 1901-04 as revealed in the Boma Law Courts." 180 In his history of the Congo, S.J.S. Cookey places the date even earlier: "It is clear, then, that in the period after 1885 there was abundant evidence on which the British government could have justified an intervention in the Congo if this had been desired." 181

Eventually, the wave began to crest across Europe, and "[b]eginning in 1900 voices began to be raised in Europe against this Belgian ruler who had his employees cut off people's hands."'182 By 1903, "the protest against the Congo system was reaching enormous proportions and it was essential for the king-sovereign to begin putting his house into some semblance of order."'183

Although the Belgians were not enthusiastic about their king's colonial adventure, neither was there widespread condemnation in response to these reports. Until at least 1903, the eminent Belgian historian Jean Stengers writes, "the Belgians had a clear conscience about the Congo. They were satisfied that King Leopold had brilliantly ensured the prosperity of his State. The time was past when the Congo, close to bankruptcy, had had to make repeated appeals for financial help from Belgium." 184 This might be attributed in part to lack of information. When word of atrocities in the Mongalla district reached Belgium in the 1900, "there was an outburst of feeling in Belgium," Doyle (otherwise quite negative in his assessment of the Belgians) reported, "showing that it is only their ignorance of the true facts which prevents the inhabitants of that country from showing the same humanity as any other civilized nation would do."185 In part, too, Belgium was resistant to lecturing, especially from the British, whose hands were hardly clean after the Boer War and other colonial misadventures. ${ }^{186}$

The year 1903 marked a turning point. In early 1903, an official bulletin was released acknowledging the existence of the massive Domaine in the Congo, which had been created by secret decree as early as 1896.187 In June 1903, King Leopold issued another bulletin, which Morel says "was translated into English and lavishly distributed in [England]."188 It claimed that " $[\mathrm{t}]$ he receipts of the Domain, as all the other public receipts, are deposited in their integrity in the State treasury....." The very existence of this crown

180. DOYLE, supra note 113, at 51.

181. COOKEY, supra note 117 , at 51.

182. REYBROUCK, supra note 47, at 90; id. at 96 ("From 1900 on increasingly clear indications began coming in concerning the atrocities in the Free State. They were not immediately given credence.").

183. COOKEY, supra note 117 , at 17 .

184. MOREL, supra note 82, at 221.

185. DOYLE, supra note 113 , at 42

186. REYBROUCK, supra note 47, at 96; see also MOREL, supra note 82, at 221-22.

187. MOREL, supra note 82, at 139.

188. Id. 
domain had only just been officially acknowledged. But a month later, the Belgian Premier in fact acknowledged that, as Morel summarizes, "revenues from the 'Crown demesne' were not paid into the CFS Treasury, and were not publicly accounted for!"189 In other words, revenues went into Leopold's pocket.

As recounted in detail above, ${ }^{190}$ the abuse of the Congolese and the misuse of CFS funds was a prominent part of Belgian political discourse by that time, so it is difficult to imagine that any investor after that point could deny knowledge of the facts that at least arguably rendered Leopold's debts odious.

In any event, the publication of Roger Casement's report in 1904 and of Leopold's own handpicked Commission in 1905 spelled the end of the road. According to historian Roger Anstey, "only with the appearance of Casement's report did the existence of widespread abuses come to be accepted; only with the foundation of the Congo Reform Association did a vehicle for a really effective campaign come into existence."191 The Commission's report "made it clear that abuses were widespread in the Congo State and that the administrative system itself was the cause of those abuses." 192 What impact it had on public opinion is difficult to discern. Some say that it "was generally recognized as a severe blow to King Leopold," 193 while others say that "the report was couched in general and unsensational terms, with the result that its impact on public opinion generally was as slight as its effect upon lawyers, politicians and those who knew how to read such a document was considerable."194

Bottom line: News of Leopold's abuses and personal greed had emerged in the international press as early as 1890 . They were widely and credibly documented - with almost no credible evidence in the other direction. For our purposes, this suggests that while there may have been creditors during the early years (at the time of the 1888 lottery loan, for example) who thought they were lending to a great humanitarian who was seeking to save the CFS from the evils of slavery, there should have been suspicion about these humanitarian claims just a few years into his rule.

As described above, ${ }^{195}$ Leopold engaged in borrowing all through his rule. Even his initial bond issue went half-sold in 1888, and he used the remaining unissued bonds as a type of currency to pay debts all through the

189. Id.

190. See supra Section II.B.

191. ANSTEY, supra note 47, at 13; see also ASCHERSON, supra note 36, at 257 ("The report of the Enquiry Commission, when it finally emerged, supported almost every one of the hostile analyses already performed on the Congo State.").

192. ANSTEY, supra note 47 , at 15 .

193. COOKEY, supra note 117 , at 148 .

194. ANSTEY, supra note 47, at 15.

195. See supra Section I.A. 
rest of his rule. Indeed, the historian Robert Harms reports that Leopold gave two trunks full of these unissued bonds to his French prostitute mistress immediately before his death. ${ }^{196}$ There was therefore at least a portion of the Leopoldian debt where creditor knowledge of his misbehavior could be inferred. That means that the third and final factor of the Sackian definition of odious debt was also satisfied. And yet not only did Belgium take on that debt, we see no evidence that anyone thought the law of odious debts gave it a legal right to refuse the debt.

\section{What Did the Market SEE? LEOPOLDIAN BOND PRICES AND YIELDS}

In this Section, we use data on prices and yields for a set of CFS bonds to examine the question at the heart of this article: Was there a recognition, in the context of Leopold's removal as sovereign of the CFS in 1908, of anything resembling a doctrine of odious debts? Thus far, we have found no such evidence in either the academic literature, the parliamentary records, or the financial press. Here, we look directly to the markets.

Building on the work of scholars such as Stephanie Collet, we use bond price data to discern whether the financial markets expected certain odious debts to be repudiated. If the markets did differentiate between those bonds more likely to be deemed odious and those less likely to be, that would suggest that the markets recognized something akin to a doctrine of odious debts. That differentiation is what Collet finds in her paper analyzing Spanish bonds in the context of the Spanish-American settlement in 1898, where the market seemed to predict that the Americans would refuse to take responsibility for the more odious of the Cuban debts. ${ }^{197}$

As discussed in the prior Section, news of King Leopold's misdeeds was widely reported as of 1903 . Since creditor knowledge is part of the classic definition of odious debts, we should - if the doctrine existed at the timesee the markets treat CFS bonds differently as a function of whether they were issued before or after 1904. And this deviation in bond prices should have shown up at the point in time when annexation by Belgium began to be factored in by the markets.

The precise date when annexation would have been factored in to market prices is hard to pinpoint, but it should have begun by November 1906. That is the point at which Britain and the United States made clear that unless action was taken by Belgium to eject Leopold from control of the CFS, they would be forced to take steps of their own, such as organizing

196. Harms, supra note 37 , at 357.

197. See Collet, supra note 23 , at 364-65. 
an international convention to determine the future of the Congo. ${ }^{198}$ Initially, the annexation plan was controversial in Belgium and resisted by the anti-colonialist wing of parliament. ${ }^{199}$ The Belgian government pushed for it, though, and a treaty of cession was signed on November 28, 1907. And eventually a number of the legislators switched votes, on the grounds that there was a humanitarian role for Belgium to play in the Congo, and final approval by parliament was achieved on October 18, 1908.200 If annexation by Belgium made it less likely that the odious debts would be paid, the above-mentioned deviation in bond prices should have manifested itself in an increasing fashion around these three dates in November 1906, November 1907, and October 1908.

We can also test the possibility that the definition of odious debts at the time was looser than the classic Sackian version that requires creditor culpability. If, for example, the version of the doctrine was one where all that had to be demonstrated was that the loan proceeds were used in ways inimical to the interests of the populace on whose back the loans were made, then we should see all of the CFS bonds (regardless of date of issue) take a dip in value upon news of the annexation by Belgium.

Table 1 reports all of the loans and bonds issued by the CFS during Leopold's years in control, starting from 1887 and going to 1908.

Table 1: List of Loans Issued by the Congo Free State 201

\begin{tabular}{|l|l|l|l|l|}
\hline Loan & Decree & $\begin{array}{l}\text { Amount in } \\
\text { BEF }\end{array}$ & Convertibility & \multicolumn{1}{|c|}{ Other elements } \\
\hline $\begin{array}{l}2.5 \% \\
1887 \text { loan }\end{array}$ & 5 July 1887 & 422,200 & No mention & $\begin{array}{l}\text { As reimbursement for } \\
\text { former member of the } \\
\text { Comité d'Etudes du } \\
\text { Haut Congo }\end{array}$ \\
\hline $\begin{array}{l}1888 \\
\text { Lottery } \\
\text { Loan }\end{array}$ & $\begin{array}{l}7 \text { February } \\
1888\end{array}$ & $150,000,000$ & No mention & Lottery \\
\hline $\begin{array}{l}4 \% 96 \\
17 \text { October }\end{array}$ & $1,500,000$ & $\begin{array}{l}\text { Not } \\
\text { convertible } \\
\text { for ten years } \\
\text { after the issue }\end{array}$ & $\begin{array}{l}\text { lssued to cover } \\
\text { linktraordinary expenses } \\
\text { the Congo }\end{array}$ \\
\hline $4 \% 1898$ & 14 June & $12,500,000$ & Not & Issued to cover \\
\hline
\end{tabular}

198. Robert SENELle \& EMILE CléMENT, LÉOPOld II ET LA CHARTE COLONIALE 49-50 (2009).

199. That original 1901 charter envisioned active involvement by the monarch (at the time, Leopold). See GuY VAnthemsChe, Belgium And THE CONGO 1885-1980, at 41 (Alice Cameron \& Stephen Windross trans., 2012).

200. Id.

201. Situation Financière et Budget Colonial, and Fonds d'Amortissement de l'Emprunt à lot de l'E.I. (on file in box 590 in the MinFin Oud files at the Archives Générales, du Royaume); Congo Belge, Recueil Administratif des Finances, Fascicule II (1912) (on file in box 592 in the MinFin Oud files at the Archives Générales, du Royaume). 


\begin{tabular}{|l|l|l|l|l|}
\hline & 1898 & & $\begin{array}{l}\text { convertible } \\
\text { for ten years } \\
\text { after the issue }\end{array}$ & $\begin{array}{l}\text { extraordinary expenses } \\
\text { linked to public works in } \\
\text { the Congo }\end{array}$ \\
\hline $4 \% 1901$ & $\begin{array}{l}15 \text { October } \\
1901\end{array}$ & $50,000,000$ & $\begin{array}{l}\text { Not } \\
\text { convertible } \\
\text { before 1922 }\end{array}$ & $\begin{array}{l}\text { Issued to cover } \\
\text { extraordinary expenses } \\
\text { linked to public works in } \\
\text { the Congo }\end{array}$ \\
\hline $\begin{array}{l}3 \% \\
1904202\end{array}$ & $\begin{array}{l}1^{\text {st }} \\
\text { February } \\
1904\end{array}$ & $30,000,000$ & $\begin{array}{l}\text { Not } \\
\text { convertible } \\
\text { for ten years } \\
\text { after the issue }\end{array}$ & $\begin{array}{l}\text { Issued to cover } \\
\text { extraordinary expenses } \\
\text { linked to public works in } \\
\text { the Congo }\end{array}$ \\
\hline $4 \% 1906$ & 3 June 1906 & $10,000,000$ & $\begin{array}{l}\text { Exchangeable } \\
\text { for a 3\% } \\
\text { Belgian loan } \\
\text { in case of } \\
\text { annexation } \\
\text { (option valid } \\
\text { for five years) }\end{array}$ & $\begin{array}{l}\text { Linked to railway } \\
\text { construction. Advance } \\
\text { for an authorized issue } \\
\text { to take place later }\end{array}$ \\
\hline $\begin{array}{l}4 \% \\
\text { Treasury } \\
\text { Bills }\end{array}$ & & $2,040,000$ & & $\begin{array}{l}\text { Advance for an } \\
\text { authorized issue to take } \\
\text { place later }\end{array}$ \\
\hline
\end{tabular}

Of the loans described above, we set aside the loan of 1887, the lottery loan of 1888, and the Treasury Bills, because of a combination of their unusual features and inadequate pricing data.

Data on weekly prices ${ }^{203}$ for the remaining CFS bonds in the Table was drawn from the Courrier de la Bourse et de la Banque. ${ }^{204}$ The Courrier de la Bourse et de la Banque gave just one price for the 1896 and 1898 loan, which had similar characteristics. We thus treat these bonds as a single issue. Our sample ranges from January 1900 to December 1910. In general, prices move from one week to the other, suggesting bonds were traded regularly. To set these prices into perspective we also collected prices for the four percent 1909 bond issued by the Belgian Congo 205 and prices for a representative Belgian bond.

202. This bond as well as the previous one only met limited success. An internal memo from the Belgian Ministry of Finance states that only half the three percent loan had actually been issued and a notable part of the four percent loan was still available for sale. Emprunts Décrétés par l'Etat Indépendant depuis 1901 (on file in box 589 in the MinFin Oud files at the Archives Générales, du Royaume).

203. Prices published on Friday (and in case of public holiday, the earliest date before).

204. The Lottery Loan was excluded because its price was mostly driven by the value of the portfolio used as guarantee which was regularly reported by the press (JOURNAL DES FINANCES, May 24, 1902; JOURNAL DES FINANCES May 9, 1908; JOURNAL DES FINANCES, June 20, 1908) but also because of its complexity which was duly noted at the time (JOURNAL DES FINANCES, Oct. 4, 1902; JOURNAL DES FINANCES, Oct. 17, 1903). Data on the Treasury Bills and the 1887 loan was unavailable.

205. Decree of January 30, 1909, amount issued 6,800,000 BEF, coupon four percent, nonconvertible before 1920 , to be amortized in ninety years. 
To compare bonds with different maturities and different coupons, we compute the yield to maturity of the various bonds. Yields to maturity are the standard measure to gauge the returns of fixed-income securities. The 1896, 1898, and 1906 loans were perpetuities. The 1901 and 1909 loans did not have a specific maturity, but a sinking fund was created to do buy backs on the market and eventually extinguish the debt after 99 and 90 years, respectively. We treat these bonds as if they had these maturities under the assumption that bondholders whose bonds had been recalled would use the proceeds of the sale to buy back a similar bond in order to keep the balance of his portfolio. 206

Figure 1 provides the yields of the various bonds. ${ }^{207}$

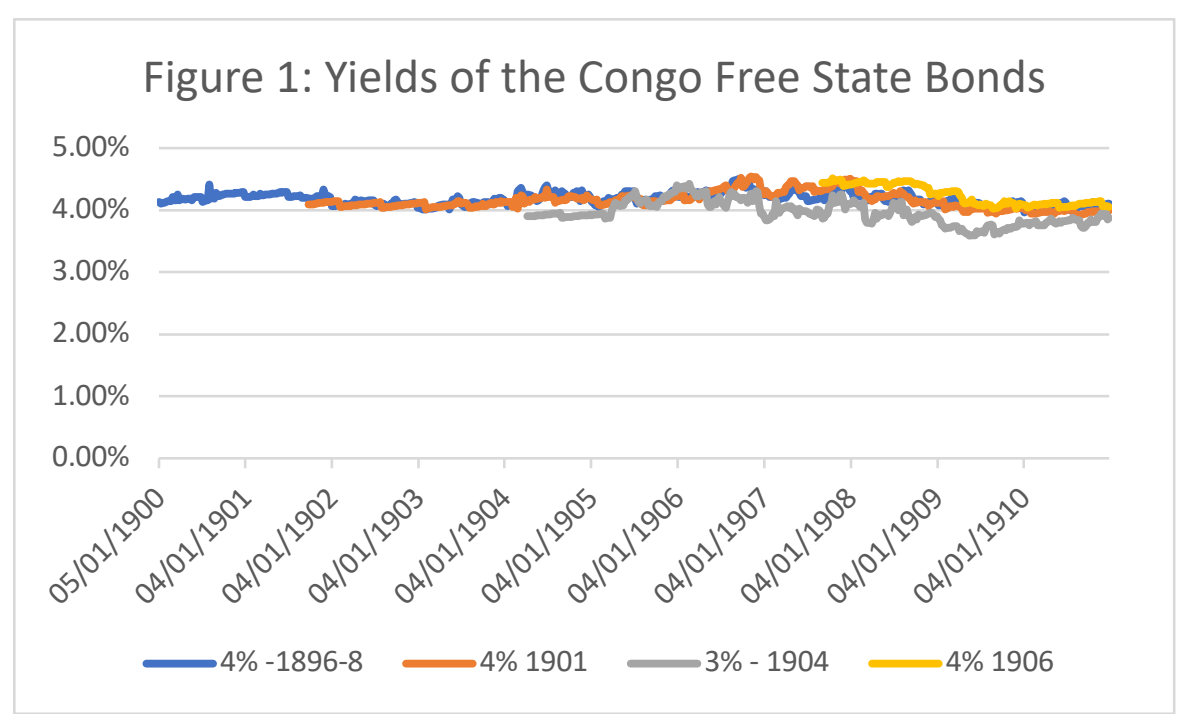

Figure 1 shows the yields on the different bonds to be extremely close, with the yields on the 1901 three percent loan slightly lower than the others. Table 2, which provides descriptive statistics for the yields of the various bonds, confirms this impression.

Table 2: Descriptive statistics of the yields to maturity of the Congo Free State bonds 208

\begin{tabular}{|c|c|c|c|c|}
\hline & \multicolumn{3}{|c|}{ Congo Free State } \\
\hline & $\begin{array}{c}1896-1898 \\
4 \% \text { loan }\end{array}$ & $4 \% 1901$ & $3 \% 1904$ & 4906 \\
\hline
\end{tabular}

206. For a discussion of this technique, see Collet \& Oosterlinck, supra note 13, at 210-16. 207. Courrier de la Banque et de la Bourse (1900-1910), authors' computation. 208. Id. 


\begin{tabular}{|l|c|c|c|c|}
\hline Period & $1900-1910$ & $\begin{array}{c}\text { September } \\
1901-1910\end{array}$ & $\begin{array}{c}\text { April 1904- } \\
1910\end{array}$ & $\begin{array}{c}\text { September } \\
1907-1910\end{array}$ \\
\hline Minimum & $3.96 \%$ & $3.91 \%$ & $3.59 \%$ & $4.03 \%$ \\
\hline Maximum & $4.50 \%$ & $4.54 \%$ & $4.42 \%$ & $4.51 \%$ \\
\hline Median & $4.18 \%$ & $4.13 \%$ & $3.93 \%$ & $4.14 \%$ \\
\hline Mean & $4.18 \%$ & $4.15 \%$ & $3.96 \%$ & $4.24 \%$ \\
\hline
\end{tabular}

Since the bonds were issued at different points in time, the number of observations and the period covered differ across bonds. Despite this, the descriptive statistics show a very similar pattern for the various CFS bonds with yields ranging from $3.59 \%$ to $4.54 \%$. Over a period of ten years, these figures strongly suggest that the market (a) made no distinction among the bonds as a function of odiousness and (b) generally believed that all of the bonds would be honored.

As a comparison point, it is helpful to consider similar historical instances where particular debts of a sovereign were denounced as legally problematic and those denounced bonds did suffer significant market penalties. The two such instances around the time of the annexation of the Belgian Congo are from the aforementioned U.S.-Spain treaty in 1898 and the Tsar's issuance of a bond in 1906 without proper legislative approval.

The yield pattern we see for the CFS bonds stands in stark contrast with what Collet and Oosterlinck find for the Tsar's problematic 1906 bond and what Collet finds with the dodgy Cuban five percent loan that the Americans refused to take responsibility for. ${ }^{209}$ In both cases, the market imposed a significant penalty of multiple hundreds of basis points on the dodgy bonds as compared to their virtuous counterparts. We see nothing of the sort with the CFS bonds. The market treats the dodgy and the virtuous debts the same, suggesting no difference in expectations of repudiation. ${ }^{210}$ Reporting in the financial press confirms this view. 211

209. See Collet, supra note 23, at 374; Collet \& Oosterlinck, supra note 13, at 213.

210. A possible complicating factor with the foregoing analysis is that several of the bonds that we examine had conversion options. The bond prices thus reflect the price of the expected revenues derived from holding the bond minus the value of the option. Conversion options thus affect the yields to maturity. Hence, in theory, by not taking this conversion option into account we overestimate the yield to maturity for bonds with these options. Any overestimation, however, is likely to be small. During our sample period only two bonds (1896 and 1898 loans) could be converted. Yet, their yields are very close to the yields of the other four percent loans in our sample suggesting the market did not give much value to the option.

211. The following quote from the October 24, 1908 issue of the Journal des Finances, is an example: The law of annexation of Congo to Belgium, whose text has just been published in the Belgian Official Journal, draws attention of the market for these securities. Although the law has specified that the debts of the colony and the metropolis will remain separate, it is clear that Belgium is becoming morally 


\section{CONCLusion}

The doctrine of odious debts is perhaps the most debated legal doctrine in international finance. And almost every discussion of this doctrine begins by invoking a set of debt repudiations from the turn of the twentieth century-most famously, the United States' repudiation of certain Spanish debts backed by Cuban revenues at the conclusion of the Spanish American war.

But the scholarly and historical debate about odious debt has ignored one especially remarkable change of government: The removal of King Leopold II from sovereign control of the CFS in 1908. Because of his astoundingly odious rule, Leopold was ultimately forced to surrender control of his personal colony. And yet the debts he incurred on the backs of the people of the CFS were not imposed on him personally, as the odious debt doctrine would require. Instead, those debts were kept squarely on the Congolese.

We embarked on this project because we wanted to know why the debts had not been repudiated. We imagined that we would find in the historical record interesting debates about the costs and benefits of repudiation among legislators in the Belgian parliament. After all, part of the motivation for Belgium taking over control of the CFS from Leopold was to remedy the humanitarian crisis Leopold had created. Further, a significant concern in Belgium - a country that had thus far had resisted the impulse to become an imperial power-was the economic cost of running a distant colony. Surely, therefore, there must have been debate over whether to do what the Americans had done just a decade prior.

But we find no evidence of any such debate-not in the parliamentary debates, not in the historical accounts, and not in the financial data. Best we can tell, there was no understanding in 1908 in Belgium that there was a legal option to repudiate King Leopold's odious debts. That tends to cast doubt on whether the doctrine of odious debts was actually recognized at the time.

Perhaps the CFS was unique, however, such that the treatment of Leopold's debts should not be taken as evidence against the historical foundation of the odious debts doctrine more broadly. While we cannot rule out that possibility, we also find it hard to accept the arguments that would distinguish it.

First, maybe the Leopoldian debts were different from typical sovereign

responsible for servicing the Congolese debt, in the same way that the French state is morally responsible for the debts of his colonies. However, we know the first-class security of Belgian finances. It is therefore ensured on the stock market that the prices of the Congo Lots, which, in recent days, are already showing signs of effervescence, are to quickly exceed the price of 100 francs. JOURNAL DES FINANCES, Oct. 24, 1908. 
obligations because he controlled the CFS in his personal capacity. In effect, it was his property. But this argument makes the case for the applicability of the odious debt doctrine even stronger. The core of that doctrine is the recharacterization of the debts incurred by despotic leaders in the name of the state as their personal debts. If Leopold's debts were personal all along, all the more reason to regard them as odious.

Second, maybe Belgium was so isolated from the international legal community in 1908 that the U.S. repudiation of Cuban debts in 1898 had not fully penetrated the debate. This narrative is implausible even within the narrative about the CFS itself, given the active and heated debate among international law luminaries in the 1880s about whether King Leopold should be allowed to take individual control of the CFS.

Third, maybe the colonial context was different. Maybe oppression of a colonial peoples, while purporting to civilize them, was not considered problematic enough to justify the invocation of the odious debt doctrine. The flaw here is that these were essentially the grounds that the United Sates invoked in repudiating the Cuban debt, purporting to care about the welfare of a colonial people and their right to mount an independence movement against an oppressive imperial power. ${ }^{212}$

Fourth, the historical record tells us that a part of the price that Leopold negotiated for, when he sold sovereign control of the CFS to Belgium, was that Belgium take on the CFS debts. But the suggestion that Leopold had any leverage here is strange given both that he had already sold Belgium the option to annex the CFS years prior. Further, this was no ordinary market transaction. There was only one buyer and the seller had no option but to sell. It seems unlikely that Leopold would have been able to force Belgium to take on the CFS debts if Belgium had not believed itself obligated to do so.

We are sympathetic to the need for a rule by which creditors bear some responsibility for making sure that their lending does not facilitate oppression of subjugated populations. But, at least based on our study, the historical record seems like a shaky foundation on which to rest such a doctrine. Our energies would be better spent in arguing for a new treaty regime.

212. SACK, supra note 133, at 162 (citing Treaty Series, no. 4, 1919, at 26); Michalowski, supra note 20, at 17 (summarizing the American argument against repaying the Cuban debts incurred under Spanish rule). 
Appendix 1: List of banks involved in the issue of the 1888 Lottery loan and number of bonds subscribed

In 1888

La Société Générale pour favoriser l'Industrie nationale 7500

La Banque de Paris et des Pays-Bas, suecursale de Bruxelles 5000

La Banque de Bruxelles $\quad 5000$

Léon Lambert, banquier, à Bruxelles $\quad 5000$

Philippson Horwitz \& $C^{\circ}$, banquier, à Bruxelles 4000

Balser et $\mathrm{C}^{\circ} \quad 2000$

Cassel et $\mathrm{C}^{\circ} \quad 2000$

In 1902

La Société Générale pour favoriser l'industrie et le commerce 7500

La Banque de Paris et des Pays-Bas, suecursale de Bruxelles 5000

La Banque de Bruxelles $\quad 5000$

Léon Lambert, banquier, à Bruxelles $\quad 5000$

Edouard Empain, banquier, à Bruxelles $\quad 4000$

E.M. Philippson, banquier, à Bruxelles $\quad 4000$

La Banque d'Outremer $\quad 4000$

La Société Générale Africaine $\quad 2500$

La Société Asiatique $\quad 1500$

Balser et $\mathrm{C}^{\circ} \quad 2000$

Cassel et $\mathrm{C}^{\circ} \quad 2000$

La Succursale du Crédit générai Liégois, à Bruxelles $\quad 1500$

La Banque Internationale de Bruxelles 1500

La Caisse générale de Reports et de dépôts $\quad 1500$

Josse Allard, banquier, à Bruxelles $\quad 1000$

J. Matthieu et fils 1000

Le Crédit Général de Belgique $\quad 1000$

Source: Contract (Feb. 8, 1888) (on file in box 587 in the MinFin Oud files at the Archives Générales, du Royaume) and Emprunt de 1888, Contrat du 28 Novembre 1902 Avec les Banquiers Belges (Nov. 28, 1902) (on file in box 591 in the MinFin Oud files at the Archives Générales, du Royaume). 